Illinois State University

ISU ReD: Research and eData

Theses and Dissertations

3-14-2016

\title{
In The Shadow Of The Great Firewall: Censorship And Surveillance During Hong Kong's Umbrella Movement
}

Christine Andrelczyk

Illinois State University, christine.andrelczyk@gmail.com

Follow this and additional works at: https://ir.library.illinoisstate.edu/etd

Part of the Asian Studies Commons, Political Science Commons, and the Quantitative, Qualitative, Comparative, and Historical Methodologies Commons

\section{Recommended Citation}

Andrelczyk, Christine, "In The Shadow Of The Great Firewall: Censorship And Surveillance During Hong Kong's Umbrella Movement" (2016). Theses and Dissertations. 488.

https://ir.library.illinoisstate.edu/etd/488

This Thesis is brought to you for free and open access by ISU ReD: Research and eData. It has been accepted for inclusion in Theses and Dissertations by an authorized administrator of ISU ReD: Research and eData. For more information, please contact ISUReD@ilstu.edu. 


\title{
IN THE SHADOW OF THE GREAT FIREWALL: CENSORSHIP AND SURVEILLANCE DURING HONG KONG'S UMBRELLA MOVEMENT
}

\author{
Christine Andrelczyk
}

\section{Pages}

Through a case-study analysis, this project investigates why the People's Republic of China eschewed overtly repressive tactics and instead relied on subtle methods of coercion, such as surveillance and censorship, to mitigate activism during Hong Kong's pro-democracy Umbrella Movement. Drawing on historical evidence, reports, and quantitative data, this research explores the significance of subtle repression and coercion as it relates to the process of authoritarian consolidation in China and Hong Kong.

KEYWORDS: Censorship, Hong Kong, Informational Communication Technologies, Umbrella Movement 
IN THE SHADOW OF THE GREAT FIREWALL: CENSORSHIP AND

SURVEILLANCE DURING HONG KONG'S

UMBRELLA MOVEMENT

CHRISTINE ANDRELCZYK

A Thesis Submitted in Partial

Fulfillment of the Requirements

for the Degree of

MASTER OF SCIENCE

Department of Politics and Government

ILLINOIS STATE UNIVERSITY

2016 
Copyright 2016 Christine Andrelczyk 
IN THE SHADOW OF THE GREAT FIREWALL: CENSORSHIP AND

SURVEILLANCE DURING HONG KONG'S

UMBRELLA MOVEMENT

CHRISTINE ANDRELCZYK

COMMITTEE MEMBERS:

Michaelene Cox, Chair

Osaore Aideyan

Noha Shawki 


\section{CONTENTS}

CONTENTS

CHAPTER

I. INTRODUCTION 1

II. REVIEW OF RELATED LITERATURE 10

$\begin{array}{ll}\text { ICTs and autocracy } & 13\end{array}$

Empowering the government 13

$\begin{array}{ll}\text { A cautious take } & 20\end{array}$

ICTs: Destabilizing autocracy 23

$\begin{array}{lll}\text { III. } & \text { THEORY }\end{array}$

Authoritarian consolidation $\quad 29$

Collective action 34

IV. RESEARCH DESIGN AND METHODS 39

V. BACKGROUND AND CONTEXT 42

Timeline of events 47

Role of ICTs in the Umbrella Movement 49

Censorship $\quad 49$

Surveillance $\quad 52$

$\begin{array}{ll}\text { VI. ANALYSIS } & 56\end{array}$

$\begin{array}{lll}\text { VII. } & \text { CONCLUSION }\end{array}$

$\begin{array}{ll}\text { REFERENCES } & 73\end{array}$ 


\section{CHAPTER I}

\section{INTRODUCTION}

A group of university students quietly sat down in front of a government building in Hong Kong's Admiralty district on September 26, 2014. A few weeks earlier, Hong Kong media outlets had announced that the dialogue between Mainland China and Hong Kong regarding electoral reforms had fallen through. The Standing Committee of the National People's Congress, China's de facto legislature, ostensibly approved of Hong Kong's bid for national elections with one major caveat: All candidates must be handselected by the communist authorities in Beijing. "This is a fake democratic proposal," remarked Hong Kong lawmaker Albert Chan, echoing the sentiments of thousands of disgruntled and disappointed Hong Kong residents. ${ }^{1}$

The student sit-in at the Admiralty building was the culmination of a week-long boycott organized by student groups Scholarism and the Hong Kong Federation of Students. Scholarism's teenage leader, Joshua Wong, explained in a call to action that: "Political reform is the core problem for every issue. Everyone knows that under the Chinese Communist party, there is a lack of possibility to fight [for] true universal suffrage in the end...but students should stand on the front line in every century."2 Just

\footnotetext{
1 Tiffany Ap, “Can Hong Kong's July 1 pro-democracy march energize political reform bid?” CNN, July 1 , 2015, http://www.cnn.com/2015/07/01/asia/hong-kong-july-democracy-march/

2 Demetri Sevastopulo, “Teenager Joshua Wong picks up democracy baton in Hong Kong," Financial Times, September 22, 2014, http://www.ft.com/intl/cms/s/0/9d52261c-421e-11e4-9818-

00144feabdc0.html\#axzz3fDoGeZ4z
} 
two days later, the students were joined by thousands of protestors as they marched through the streets of Hong Kong's glittering, high-tech commercial district. Activists blocked key intersections, paralyzing traffic, as riot police launched canisters of tear gas into the peaceful crowd. In response to the noxious gas, activists raised umbrellas painted with pro-democracy messages, and thus the Umbrella Movement was born. ${ }^{3}$

To some, this scene might appear reminiscent of images of demonstrators in Egypt and Iran in the preceding years, where young people took to the streets amidst a storm of tweets, texts, and blog posts. The Arab Spring movement of 2011 ignited an ongoing discussion about the role of communication technology in social movements, causing journalists and scholars alike to examine how platforms like mobile phone technology and the internet could be harnessed by activists in order to disseminate prodemocratic messages and mobilize against authoritarian regimes. Egyptian president Hosni Mubarak was ousted in less than three weeks in a relatively bloodless revolution after millions of activists took to social media to express their discontent and organize mass protests. The 2009 election protest in Iran and the 2011 revolution in Tunisia were described as "Twitter revolutions," a name referencing the primary instrument utilized by activists. When Hong Kong's Umbrella Movement burst onto the international stage in 2014, one might have assumed that, like in Egypt and Tunisia in the years prior, the collective fervor of youthful activists would flood the streets and social media in equal measure and ultimately lead to another major victory for democracy. But that never happened, largely based on China's skillful handling of the movement.

\footnotetext{
3 "Hong Kong protests: Timeline of the occupation," BBC News, December 11, 2014, http://www.bbc.com/news/world-asia-china-30390820.
} 
The Umbrella movement was in fact just the most recent of a series of protests stretching back to 2003 when pro-democracy activists first expressed their discontent with the encroaching authoritarian policies of Mainland China. These protests largely spark from the struggle between Hong Kong to exert a higher degree of democratic selfrule and China's policy of centralized control. Specifically, the issues of free elections and freedom of expression have generated a high degree of public contention.

Although the frequency of Hong Kong's protests could lead observers to believe otherwise, Hong Kong is not administered by a regime that encourages free political discourse or permits government criticism. Restrictive policies imposed by the People's Republic of China are geared towards limiting the transmission of information deemed controversial, politically sensitive, or anti-government. Individuals found participating in subversive communications could realistically face arrest and imprisonment. ${ }^{4}$ On a larger scale, the government has openly engineered mass internet blackouts in regions of China embroiled in social unrest where demonstrations are believed to have been organized using technology like the internet and mobile phones. Despite such restrictions, Hong Kong has experienced a number of mass protests since 1997. This raises questions regarding how communication can be used as a tool to either advance or limit democratic progress in social movements like the Umbrella protest. Additionally, one may ask why recent social movements in Egypt and Tunisia succeeded while Hong Kong's did not, despite activists having very similar digital tools at their disposal.

\footnotetext{
${ }^{4}$ Francis L. F. Lee and Joseph M. Chan, "Professionalism, Political Orientation, and Perceived SelfCensorship: A Survey Study of Hong Kong Journalists" (Paper presented at the annual meeting of the International Communication Association, TBA, Montreal, Quebec, Canada, May 21, 2008).
} 
The relationship between communication technology and social movements is far from novel. Johannes Gutenberg's invention of the printing press in 1450 demonstrates how technological change can facilitate social change. His invention is credited with playing a key developmental role in the Renaissance, Reformation, and Scientific Revolution. More recently, Radio Free Europe was nominated for a Nobel Peace Prize in 1991 for its role in bringing down the Iron Curtain. ${ }^{5}$ Within the last decade, information and communication technologies (ICTs) have been lauded by some as a voice piece of the oppressed and tool for liberation, prompting prominent figures like Egyptian activist and Google Entrepreneur Wael Ghonim to espouse, "if you want to liberate a society, just give them the internet." ${ }^{6}$ Yet despite the rallying power of digital communication, Freedom House reported in 2015 that more countries experienced declines in freedom than gains for the ninth consecutive year despite global surges in internet and mobile phone connectivity. ${ }^{7}$ Freedom House additionally reported a major increase in surveillance and overall decline in internet freedom, despite more people than ever being connected to the web. ${ }^{8}$

\footnotetext{
${ }^{5}$ Evgeny Morozov, The Net Delusion: The Dark Side of Internet Freedom (New York: Public Affairs, 2012), 20.

${ }^{6}$ Jürgen Habermas, The Theory of Communicative Action: The Critique of Functionalist Reason (Cambridge: Polity Press, 1987); Cyrus Farivar, interviewed by Tony Cox, Internet: Road to Democracy...or Elsewhere? NPR, August 15, 2011.

7"Freedom in the World 2015," Freedom House, accessed February 14, 2016, https://freedomhouse.org/report/freedom-world/freedom-world-2015\#.VsCv1_krLIU; "Mobile Phone Internet User Penetration Worldwide from 2012 to 2017," Statista, accessed July 8, 2015, http://www.statista.com/statistics/284202/mobile-phone-internet-user-penetration-worldwide/ ${ }^{8}$ Uri Friedman, "Will the World Grow More Authoritarian in 2014?" The Atlantic, January 6, 2014, http://www.theatlantic.com/international/archive/2014/01/will-the-world-grow-more-authoritarian-in$2014 / 282840 /$
} 
As many authoritarian regimes around the world defy the inevitable collapse outlined in democratic transition theory, ${ }^{9}$ a growing body of research calls into question the liberating effects of ICTs and even demonstrates how ICTs can be effectively used against the populace. Cyber-communication has given rise to extensive and elaborate surveillance systems capable of tracking and recording details about internet users, essentially stripping away the protective shield of privacy. Skeptics are also concerned by the medium's susceptibility to transmitting false information and giving rumors the veneer of fact. ${ }^{10}$ Contrary to popular assumptions, China in particular is actively promoting the usage of ICTs in order to facilitate economic growth, a policy which demonstrates China's confidence in its own abilities to adapt to the challenges posed by digital communication. ${ }^{11}$ Former U.S. Secretary of State Hillary Clinton succinctly tackled the duality of global communication technologies in a recent speech, stating that:

Amid this unprecedented surge in connectivity, we must also recognize that these technologies are not an unmitigated blessing. These tools are also being exploited to undermine human progress and political rights. Just as steel can be used to build hospitals or machine guns, or nuclear power can either energize a city or destroy it, modern information networks and the technologies they support can be harnessed for good or for ill. The same networks that help organize movements for freedom also enable al-Qaida to spew hatred and incite violence against the innocent. And technologies with the potential to open up access to government and promote transparency can also be hijacked by governments to crush dissent and deny human rights. ${ }^{12}$

Despite this seemingly clean division in technology's perceived political alignment, the reality is much more nuanced. In truth, ICTs are simply tools without any inherent moral, political, or ethical substance, and are therefore impossible to generalize

\footnotetext{
${ }^{9}$ Democratic transition theory explains the process through which non-democratic societies evolve towards democracy. (Sujian Guo, "Democratic Transition: A Critical Overview," Issues \& Studies 34 (1999): 133148.)

${ }^{10}$ Morozov, The Net Delusion: The Dark Side of Internet Freedom, 17.

${ }^{11}$ Qinfeng Zhu and Marko M. Skoric, “The Role of ICT's in Adaptive and Persistent Authoritarianism: A Study of China at the Administrative Division Level" (paper presented at $47^{\text {th }}$ Hawaii International Conference on System Science, Waikoloa, Hawaii, January 6-9, 2014).

12 Hillary Rodham Clinton, "Remarks on Internet Freedom," (presentation, Washington D.C., January 21, 2010).
} 
from case to case. Simply because ICTs were integral to drastic political changes in Egypt does not mean all pro-democracy movements will experience the same level of success. In fact, in some cases, governments can expertly wield these digital tools to repress social movements and protect their own power.

Broadly, this project seeks to understand why the Hong Kong protests failed to bring about meaningful democratic reforms despite the immense popular support of the movement. Even compared to earlier social movements in Hong Kong, which successfully pressured China to back down or negotiate on controversial policies, the Umbrella Movement was a failure. ${ }^{13}$ Yet, through the months of protests gripping Hong Kong, China barely lifted a finger in terms of employing coercive tactics like violence or physical intimidation, the traditional weapons in any authoritarian state's arsenal. In the past, China has not shied away from being blatant with its tactics. When unrest erupted in China's Xinjiang province in 2009 , the government shut down the entire internet for ten months until protests subsided. ${ }^{14}$ The abortive "Jasmine Revolution" of 2011, directly inspired by Tunisia's own revolution, was met with brutality as activists were beaten, arrested, and disappeared by Chinese authorities. ${ }^{15}$ Other than tear gas and a police perimeter, which is not uncommon even in democratic societies, nothing blatantly repressive took place in Hong Kong, yet the movement was shut down just the same amid

\footnotetext{
13 “Huge Protest Fills HK Streets,” CNN.com, last modified July 2, 2003. http://edition.cnn.com/2003/WORLD/asiapcf/east/07/01/hk.protest/; "Hong Kong backs down over Chinese patriotism classes.” BBC News, September 8, 2012. http://www.bbc.com/news/world-asia-china19529867

${ }^{14}$ Chris Hogg, "China restores Xinjiang internet,” BBC News, May14, 2010. http://news.bbc.co.uk/2/hi/8682145.stm.

${ }^{15}$ Damian Grammaticas, "Calls for protests in China met with brutality," BBC News, February 28, 2011. http://www.bbc.com/news/world-asia-pacific-12593328
} 
reports of coercion, surveillance, and mass censorship. The PRC approached the Hong Kong protests with a level of subtlety and sleight of hand that seems out of character compared to their handling of Mainland protests. This disparity raises the question of why the PRC approached the Umbrella Movement so differently while still ensuring that activists did not meet their goal of democratic reform.

In order to understand the reasons for the Umbrella movement's failure, we must consider how specifically the government addressed the protests and the motivation behind its actions. This paper ultimately aims to answer the question: Why did the People's Republic of China (PRC) use ICTs to limit activists' freedom of speech and collective action during the Umbrella Movement? While the PRC's ultimate motivation of upholding the balance of power is clear, it is unknown why China did not crack down on Hong Kong's activists with the same blunt, repressive force it has historically used against Mainland social movements.

While the role of ICTs in the hands of activists is well researched, less attention has been focused on how governments utilize the same technology to defuse collective action in order to maintain their grip on power. In the case of China, prior research on the government's methods of social control have largely focused on Mainland groups and activists. ${ }^{16}$ China's response to the Umbrella Movement is novel for two reasons. First, China largely shied away from using physical repression. Second, the PRC sought to apply authoritarian tactics of social control to Hong Kong, a territory which enjoys legal freedom of expression and a traditionally laissez-faire approach to the exchange of ideas and opinions. Hong Kong's unique relationship with China creates an opening for

\footnotetext{
${ }^{16}$ Francis Lee, "Power and Strength of Networked Media and Connective Action: The Case of Hong Kong's Umbrella Movement," Communication Research and Practice, 6 (2016): 11-44.
} 
insightful new research. This project aims to explore and understand the technologybased methods of social control the PRC employed to both lessen the impact of and limit the momentum of the Hong Kong protest. Additionally, this project will seek to shed light on why the PRC opted to adopt ICTs for subtle methods of social control rather than relying on physical force to assert its power. Overall, the research will provide a more nuanced understanding of the methods of social control employed by modern authoritarian states.

While any conclusions drawn in this paper will not be generalizable in the sense that they can be applied to cases outside the Umbrella movement, they will nevertheless contribute to a less-explored aspect of the relationship of technology and social movements, and will shed light on the PRC's evolving approach to internal unrest. At its core, this project will provide an in-depth case study analysis of the Umbrella Movement, focusing on the specific reasons the PRC utilized ICTs to maintain their grip on power in the face of a rising tide of dissent. The events of the protest will be analyzed through the lens of authoritarian consolidation theory and collective action theory, which will provide a framework for understanding the resilience and surprisingly adaptive nature of authoritarian regimes despite external pressures to reform. An additional factor to consider, while not a primary focus of the study, is how specifically activists reacted to PRC censorship and surveillance actions.

This paper is divided into seven chapters which will provide perspective and commentary on the ongoing scholarly debate regarding ICTs and government control, and will also provide a detailed examination of Hong Kong's Umbrella protest utilizing recognized theories of authoritarian consolidation and collective action. Specifically, the 
discussion will examine why the PRC used ICTs for the purposes of subtle methods of social control, such as censorship and surveillance of pro-democracy activists. Chapter two will conduct a detailed review of related literature, compiling prior investigations related to technology, social movements, and authoritarian control and synthesizing the material into a framework for this study. Chapter three provides an overview of several key theories and how they can be applied to understanding the role technology plays in authoritarian control. Chapter four outlines the methodological approach this project is adopting, and implements the method in a case study analysis of a major pro-democratic protests that took place in Hong Kong in 2014. The fifth and sixth chapters will provide historical context for the event followed by a case study analysis of discussion of the study's results. Lastly, chapter six is the project's denouement and will focus on concluding remarks and lessons learned from the study. 


\section{CHAPTER II}

\section{REVIEW OF RELATED LITERATURE}

With over six hundred million internet users, China is the most networked country on the planet, yet has some of the tightest controls on information and digital discourse. ${ }^{17}$ A recent study observed that internet usage is ubiquitous among college students in Beijing, yet most students could not identify the iconic image of a man facing down a tank during the 1989 protests at Tiananmen Square. ${ }^{18}$ Nearly all references to the last major protest to have occurred in Mainland China have been removed from the web. ${ }^{19}$ Gaps in information such as this one raise an entire host of questions regarding the ability of ICTs to foster meaningful, deliberative discourses between individuals in politically closed environments. This research question was designed to investigate why Hong Kong's Umbrella Movement failed to achieve its objectives, despite the successful prodemocratic movements that took place in Tunisia and Egypt with the aid of ICTs and social media.

Since the Umbrella Movement's failure hinges on the PRC's ability to manage and contain the movement, this project will focus on the government's counter-measures and underlying motivations. This project is unique in that seeks to shed light on why the PRC chose to adopt ICTs for subtle methods of social control rather than relying on

\footnotetext{
${ }^{17}$ The World Factbook. Washington, DC: Central Intelligence Agency. Continually updated. https://www.cia.gov/library/publications/the-world-factbook/.

${ }^{18}$ Ibid.

${ }^{19}$ Rebecca MacKinnon,“China's 'Networked Authoritarianism,”” Journal of Democracy 22 (2011): 33.
} 
physical force to assert its power as it has historically controlled protests on the Mainland. Recent mass protests in Mainland China, such as the 2009 outbreak in Xinjiang and the 2011 Jasmine Revolution, were blatantly repressed through a combination of violence, arrests, and an extended internet blackout in the case of Xinjiang. ${ }^{20}$ The following case study will examine exactly why the PRC's tactics differed so drastically in Hong Kong.

China is a major topic of interest for scholars from a variety of disciplines, and a plethora of research exists investigating the intersection between social movements and the communist regime's elaborate system of social control. Despite the preponderance of scholarship on this particular question, the vast majority of the research concerns Mainland China with less attention focused on China's Special Administrative Regions (SARs) such as Hong Kong.

As a SAR, Hong Kong has a unique relationship with China that is not politically equivalent to that of a Mainland province. Hong Kong is technically ruled by Beijing, but the rules of their relationship are determined by the treaties and constitution co-written by the United Kingdom and China upon Hong Kong's return to China in 1997. As a result, Hong Kong's administrative and legal structure differ in key ways from China's Mainland provinces'. One major difference is that Hong Kongers are legally guaranteed the right to free speech. ${ }^{21}$ In the context of Hong Kong's Umbrella Movement, this raises the question of why Beijing interfered at all. Hong Kong's unique and markedly un-

\footnotetext{
${ }^{20}$ Chris Hogg, “China restores Xinjiang internet,” BBC News, May14, 2010. http://news.bbc.co.uk/2/hi/8682145.stm.; Damian Grammaticas, "Calls for protests in China met with brutality," BBC News, February 28, 2011. http://www.bbc.com/news/world-asia-pacific-12593328 21 "Chapter III: Fundamental Rights and Duties of the Residents," Last modified July 13, 2012, http://www.basiclaw.gov.hk/en/basiclawtext/chapter_3.html.
} 
Mainland political and legal climate also call into question whether the conclusions of studies of Mainland social movements can be applied to the Umbrella Movement. With its constitutional liberties and historically laissez-faire media, Hong Kong is unfamiliar territory to a communist regime used to having absolute control over the information and ideas shared between its citizens.

Generally speaking, the relationship between technology and political repression has been well-researched, especially as it pertains to Mainland China. Previous literature is quite diverse in terms of theoretical framework and research design, providing an interesting constellation of perspectives. Results of prior scholarship fall on a wide spectrum in terms of whether or not technology plays a role in aiding or abetting political consolidation in autocratic countries, a factor this project will seek to clarify for the case of Hong Kong. Ultimately, prior literature will be used to frame this project's understanding of why the PRC utilized ICTs to limit digital political dialogue and collective action during the Umbrella Movement despite Hong Kong's legal guarantee of freedom of speech.

The following chapter is divided into two major categories based on large divisions in prior research. The first and largest section will analyze research focused on the relationship between ICTs and authoritarian governance. For the purpose of providing a detailed review, the first section will be divided into several sub-sections, each investigating a different scholarly perspective on the relationship between government control and ICTs. A second, smaller section will provide a general overview of ICTs and democratization. This section will furnish additional context for the research question at hand. 


\section{ICTs and autocracy}

Following the Arab Spring movement, the internet and social media platforms were lauded as virtual panaceas against repressive dictatorships. In the midst of Iran's Green Revolution, the New York Times described the "quintessential twenty-first century conflict" as armed riot police versus mobile phone toting youth. ${ }^{22}$ Indeed, this perspective of ICTs as "liberation technologies" is also rooted in journalistic and scholarly literature. Prominent social movement scholars like Larry Diamond have acknowledged the democratizing potential of digital communication. ${ }^{23}$ Despite the triumphs of social media against tyranny in success stories like Egypt, there are still a number of global autocracies that seem impermeable to the transformative potential of digital communication networks. This apparent discrepancy raises questions about the effectiveness of ICTs as conduits of political change, and invites further analysis of how authoritarian governments are harnessing communication technology to solidify their own grip on power.

\section{Empowering the government}

A significant number of scholars are highly critical of cyber-utopianism-the notion that ICTs are inherently emancipatory — and are quick to explain that communication technology is not limited to the hands of activists and can just as easily be utilized by self-interested elites looking to preserve the status quo. Research in this camp probes into how authoritarian regimes utilize ICTs behind the curtain to maintain

\footnotetext{
${ }^{22}$ Nicholas Kristoff, “Tear Down This Cyberwall!” The New York Times, June 17, 2009.

${ }^{23}$ Larry Diamond, "Liberation Technology,” Journal of Democracy, 21 (2010): 69-83.
} 
social control, and questions the potential of digital communication networks as conduits for political change. This line of research advocates for a more realistic understanding of ICTs, in which the weaknesses, drawbacks, and consequences of digital communication are addressed.

One notable study directly questions the impact that digital communication technology has on social movements. Researchers hypothesized that ICTs are an effective conduit for the flow of information, but not for social organizing. They explain that usergenerated posts are most effectively used to criticize government policies, expose corruption, and call into question the system of governance by serving as a virtual alternative press, but not to mobilize mass movements. ${ }^{24}$ This can be true even in societies where the government has a strong hold on the media. Backing the argument with content analysis and contemporary examples, researchers demonstrate that recent mass social movements, such as the Iranian Green Movement, experienced a measure of success by using ICTs to disseminate images and videos which drew attention to a particular grievance. However, any attempts at actually orchestrating protests were quickly quashed by the government, therefore preventing activists from achieving any of their collective objectives. The authors also point out that freedom of information does not necessarily correlate with freedom of association, a distinction apparent in authoritarian states with relatively unrestricted digital spheres.

Research on the role of the internet and democratization in post-Soviet states concluded that even in authoritarian countries with relatively unrestricted internet access,

\footnotetext{
${ }^{24}$ Bruce Etling, Robert Faris, and John Palfrey, "Political Change in the Digital Age: The Fragility and Promise of Online Organizing," SAIS Review, 30 (2010): 40-41.
} 
pro-democracy movements are not guaranteed to take place. ${ }^{25} \mathrm{~A}$ notable case study reveals that ICTs alone are often not powerful enough to depose a highly coercive regime, or overcome deeply entrenched institutional and structural barriers. ${ }^{26}$ Additionally, the author highlights the importance of a powerful opposition movement, since ICTs alone are unable to bring political inertia to a weak or fractured opposition. ${ }^{27}$ In sum, this line of research is dubious of the assumption that ICTs have a strong standalone impact on social movements or can effect political change. In other words, ICTs are capable of effecting change only under the right social and instructional circumstances. While the argument is certainly compelling, it is uncertain if lessons learned from the post-Soviet study can be applied to China, which differs from Soviet-style top-down authoritarianism in its heavier emphasis on citizen buy-in. In sum, the societies may simply be too different for lessons learned from one to apply to both.

Another vein of research does not question the impact potential of ICTs on furthering social movements, but does caution that digital communication technologies can easily be used to strengthen and consolidate authoritarian regimes. This cautious perspective is largely based on the observation that ICTs are not exclusive to social activists, and that by treating ICTs as purely emancipatory, researchers have lost sight of how authoritarian governments have masterfully adapted technology for the purposes of surveillance, censorship and propaganda. ${ }^{28}$ Overall, the literature in this camp agrees that censorship and propaganda are particularly relevant to the case of China, where the

\footnotetext{
${ }^{25}$ Rachel Vanderhill, "Limits on the Democratizing Influence of the Internet: Lessons from Post-Soviet States,” Demokratizatsiya 23 (2015): 55-56.

${ }^{26}$ Ibid.

${ }^{27}$ Ibid.

${ }^{28}$ Morozov, The Net Delusion: The Dark Side of Internet Freedom, xiv.
} 
Golden Shield project, or Great Firewall as it is colloquially referred to in the West, forms a complex system of restrictions on the websites, content, and information that can be viewed by Chinese internet users. Authoritarian regimes rest on the control of information, and in today's digital, information-based societies, controlling the internet means controlling the flow of information.

Scholars have investigated the full-range of the authoritarian censorship arsenal, including website-blocking, deletion of politically objectionable material, and surveillance. The Arab Spring movement has allowed scholars a glimpse at how authoritarian regimes are simultaneously grappling with the challenges posed by ICTs and learning how to harness them to consolidate and defend their power. A case study of the 2009 election protests in Iran revealed the inherent duality of ICTs: While activists were flocking to social media to disseminate information and coordinate collective action, the government reacted in real-time by deploying a far-reaching censorship network, repressing online protests, and using propaganda, rumors, and false information to fuel confusion. ${ }^{29}$

In addition to understanding specifically how authoritarian governments use ICTs to protect their own rule, of equal importance is understanding why. In a recent study about censorship and self-expression in China, researchers analyze China's far-reaching internet censorship initiative in order to reverse-engineer the PRC's policy objectives, which are typically obscured by a shroud of secrecy. Researchers were somewhat surprised to discover that China did not censor all information critical of the regime, but only posts that showed a clear potential to snowball into collective action. A quantitative

\footnotetext{
${ }^{29}$ Daniel Baldino and Jarrad Goold, "Iran and the Emergence of Information and Communications Technology: The Evolution of Revolution?” Australian Journal of International Affairs 68 (2014): 19.
} 
analysis of popular key words revealed that any posts capable of inciting social mobilization were deleted, even when the apparent call to action was apolitical in nature. ${ }^{30}$ Historians point out that the influence of age-old Confucian traditions in Chinese politics have created a pattern of legitimacy earned through collective action. ${ }^{31}$ As a result, China's political elites have a long history of stemming potential collectivization by clipping social ties between individuals. ${ }^{32}$ The ruling Chinese Communist Party is acutely aware of the impact social movements have on their overall legitimacy, and have even been known to carefully encourage protests that bolster their image or re-direct popular ire towards a rival target, such as the protests against Japan's involvement in the Senkaku islands in 2012, while simultaneously quashing movements that question the CCP's ability to rule effectively. ${ }^{33}$ In the twenty-first century, this dynamic has persisted as China adapts to new forms of communication technology. Additionally, China's system of censorship reveals not only the government's focus on stemming collective action of any kind, but the system's level of sheer sophistication, complexity, and subtlety.

The element of subtlety is something that modern authoritarian regimes strive for, since research on authoritarian strategies of social control conclude that blatant coercion damages regime legitimacy. ${ }^{34}$ In response, modern censorship methods have become more discrete and geared towards thought-steering than blatantly blocking or deleting

\footnotetext{
${ }^{30}$ Gary King, Jennifer Pan, and Margaret Roberts, "How Censorship in China Allows Government Criticism but Silences Collective Expression," American Political Science Review 107 (2013): 31-34.

${ }^{31}$ Elizabeth Perry, Challenging the Mandate of Heaven: Social Protest and State Power in China (New York: M.E. Sharpe, 2002).

32 Ibid.

${ }^{33}$ Kevin McKenzie, "Troubled Waters: Security, Economic Development, And The Senkaku/diaoyu Islands," Thesis, Illinois State University, 2014, http://ir.library.illinoisstate.edu/etd/277. ${ }^{34}$ Christian Goebel, "The Information Dilemma: How ICT Strengthen or Weaken Authoritarian Rule." Statsvetenskaplig tidskrift 115, (2013): 179.
} 
undesirable information. A researcher at University of Hong Kong's China Media Project explains that China's state-run press is becoming increasingly centered around telling China's "side of the story," in other words, crafting a single state-approved narrative or agenda. ${ }^{35}$ The goal of telling China's story is the creation of a carefully engineered information gap, which quietly obscures any information that could spark widespread disapproval among the populace, all without internet users realizing it. ${ }^{36}$

At this point, it is important to note that the sophistication of technologicallyrooted, authoritarian methods of social control have evolved in step with the progress of communication technology. The complexity and effectiveness of authoritarian internet control paradigms can be broken into three generations. The first generation, spearheaded by China, is characterized by a national-level filtering scheme. ${ }^{37}$ Second generation controls are much more difficult to detect, which provides the government a screen of plausible deniability, and also extends into the country's legal and normative terrain to shape it in favor of the security structure ${ }^{38}$ The most sophisticated level of control is the third generation, which is hallmarked not by the direct intervention of the first generation, but by subtler methods of social control, such as dialogue steering, propaganda, and misinformation campaigns geared towards discrediting dissenting voices. ${ }^{39}$ Presently, China is known to implement all three generations of technology in their program, resulting in a highly sophisticated and pervasive paradigm of censorship, surveillance, and dialogue-steering. Somewhat paradoxically, spikes in global internet

\footnotetext{
${ }^{35}$ Jennifer Duggan, "Behind the Great Firewall of China," Maclean's, October 1, 2014.

${ }^{36}$ MacKinnon, "China's 'Networked Authoritarianism," Journal of Democracy, 33.

${ }^{37}$ Ronald Deibert, John Palfrey, Rafal Rohozinksi, Johnathan Zittrain. Access Denied: The Practice and Policy of Global Internet Filtering. Cambridge: The MIT Press, 2008.

${ }^{38}$ Ronald Deibert et al., Access Controlled: The Shaping of Power, Rights, and Rule in Cyberspace, Cambridge: The MIT Press, 2010.

${ }^{39}$ Ibid.
} 
user rates have created new spheres for free speech, but have also created an opening for more extensive government control. The rise of "intermediary censorship," in other words content-monitoring that the government outsources to private parties such as Internet Service Providers (ISPs) and Online Service Providers (OSPs), broaden the government's scope while allowing it to surpass its own limitations in terms of resources and personnel. These newer, decentralized methods require ICT-based corporations, such as ISPs, search engines, and blogging platforms, to be complicit with government restrictions on content and by relinquishing user data on demand. U.S.-based corporation Yahoo! came under scrutiny in 2005 after it yielded information about a Hong Kong journalist which eventually led to his arrest. ${ }^{40}$ The rise of intermediary censorship poses the greatest threat to activists in authoritarian states, who have to rely on secrecy and anonymity in order to avoid unwanted attention or punishment.

Overall, research in this vein demonstrates specific ways in which authoritarian governments are incentivized to control ICTs in order to protect their own position of power. Related scholarship indicates that prior social movement research often overlooked the capacity ICTs have to strengthen autocratic regimes, and stress the importance of further research in order to fully understand the relationship between ICTs and regime consolidation. A related camp of research, which explores the duality of ICTs, will be covered in the following sub-section.

\footnotetext{
${ }^{40}$ Ronald Deibert et al., Access Controlled: The Shaping of Power, Rights, and Rule in Cyberspace, Cambridge: The MIT Press, 2010.
} 


\section{A cautious take}

A number of scholars acknowledge that in reality nothing as simple as "us versus them" exists, and instead adopt a cautious and more nuanced approach to ICTs and regime change. Research in this vein tends to acknowledge that ICTs have the potential to strengthen or threaten authoritarian regimes in equal measure, the results of which depend exclusively on how effectively forms of digital communication are managed by the regime.

Recent research provides a detailed analysis of modern autocratic regimes' highly-networked approach to authoritarian governance, and describes how online activism has the potential to either hurt or help the regime. Specifically, researchers have demonstrated how the Chinese regime has been particularly masterful about managing digital communication in its various forms. In fact, China has been so adept at integrating ICTs, that researcher Rebecca MacKinnon coined the phrase "networked authoritarianism" to capture the full depth of its intricate strategy of social control. ${ }^{41}$ Networked authoritarianism describes how communication technology has fundamentally altered the dynamic between the government and the populace as compared to classic authoritarianism. ICTs allow individuals to express critical opinions and observations about the regime, essentially creating a space for public political dialogue, which results in a sense of freedom of expression and civic agency among digitally connected citizens. However, despite the perception of freedom, citizens under networked authoritarian states still lack formal channels of political participation, lack individual rights, and can face

\footnotetext{
${ }^{41}$ Rebecca MacKinnon, “China's 'Networked Authoritarianism,"” 36-41.
} 
repercussions like jail time if deemed a threat to the state. ${ }^{42}$ Additionally, digital activism can inadvertently strengthen autocratic regimes through broad-sweeping calls to action, like the end of one-party governance or demands for free elections, which can cause factions within the regime to join forces against the perceived, collective threat. Another study echoes this concern, describing how external threats to the party often cause hardliners and soft-liners to band together. ${ }^{43}$

The duality of ICTs can also be extended to social activists, illustrating how the digital tools used to collectivize in non-democratic societies can actually leave activists vulnerable. This is largely due to authoritarian regimes weaving their social control programs into the country's institutional and legal fabric. As touched on previously, this process occurs in three "generations," the first of which involves setting up a system of censorship, filtering, and digital surveillance, which poses the least overall risk to activists. However, the second and third generations include more invasive measures like warrantless investigations, deliberate internet black-outs, and collusion between the government and private companies regarding information control. Additionally, constructing a legal environment around information control strips away privacy protections and criminalizes certain behaviors associated with social activism. Overall, scholars acknowledge that ICTs possess a strong potential for inciting mass prodemocracy movements, but ultimately conclude that obstacles such as institutional barriers, government policy, and corporate complicity can prevent that potential from

\footnotetext{
42 Ibid.

43 Yongnian Zeng, Technological Empowerment: The Internet, State, and Society in China, Stanford University Press: Redwood City, 2007.
} 
being realized. One study of note concludes that transparency, rule of law, and accountability must be improved in order for activists to be fully protected. ${ }^{44}$

Another line of research developed a model that demonstrates how ICTs have the power to either strengthen or undermine authoritarian rule. The author of a notable study argues that even digitally-connected autocracies can resist democratization by using ICTs to systematically consolidate their own power. Certain types of digital technology promote government resilience by preventing social unrest, disseminating subtle and persuasive forms of propaganda, and by providing officials with a pulse on public opinion and social grievances. ${ }^{45}$ Related scholarship also posits that by approaching ICTs as a force to be harnessed for economic growth, the Chinese regime was also able to increase various facets of its power and therefore further entrench itself in governance. The Chinese model's capacity for resilience is exceptionally noticeable when compared to regimes that take a more aggressive stance against ICT penetration, such as Myanmar, which suffers from the economic frailty that goes hand-in-hand with an underdeveloped digital infrastructure.

Scholarship exploring the duality of ICTs recognize that technology has the capacity to either strengthen or challenge the grip of authoritarian regimes. Research in this camp largely relies on case study analyses in order to demonstrate how different regimes adapt (or fail to adapt) to the challenges posed by widespread internet and mobile phone usage. China is cited repeatedly for its ability to effectively evolve its methods of social control in order to keep up with the changing technological landscape. Research

\footnotetext{
44 Ibid

${ }^{45}$ King, Pan, and Roberts, "How Censorship in China Allows Government Criticism but Silences Collective Expression," 326-343.
} 
also cites how ICTs can actually open up social activists to certain vulnerabilities, which in turn affects their ability to successfully mobilize against a regime. Since a huge component of regime resilience is the ability to mitigate external threats, such as mass social movements, the next section will delve into the relationship between ICTs and social activism.

\section{ICTs: Destabilizing autocracy}

Part of the broader dialogue of regime change and collective action is the impact that ICTs have on social activism. This vein of research is integral to the research topic at hand because, as explained in the previous section, collective action can play a direct role in facilitating regime change, and a large body of scholarship indicates that ICTs strengthen social movements. This section will provide an overview of recent research on ICTs and democratization, with the goal of providing a big picture understanding of why authoritarian regimes are concerned with keeping a tight rein on communication technologies.

Despite the preponderance of censorship mechanisms, some scholars remain optimistic that the ability to participate in digital, public discourses is enough to fuel collective energy and invoke meaningful political change. This school of thought stresses that the sense of agency and participation fostered by digital discourse cannot be mitigated by censorship. ${ }^{46}$ Prominent social movement scholar Larry Diamond encapsulates ICTs' potential for democratization in the term "liberation technology." The

\footnotetext{
${ }^{46}$ Neal A. Palmer and Douglas D. Perkins, "Technological Democratization: The Potential Role of ICT in the Social and Political Transformation of China and Beyond," Perspectives on Global Development and Technology 11 (2012): 456-479.
} 
term includes any form of ICT capable of increasing political, economic, and social liberties that "enables citizens to report news, expose wrongdoing, express opinions, mobilize protest, monitor elections, scrutinize government, deepen participation, and expand the horizons of freedom." ${ }^{47}$ Diamond highlights newer forms of technology, like the internet and mobile phones, as being more conducive to mobilization than older, passive forms of technology like the radio and television. The active, participatory nature of newer generation ICTs create a decentralized environment ripe for grass roots action and the rapid sharing of information among countless users. While Diamond certainly takes a more optimistic stance for technology's pro-democratic potential, he ultimately concludes that technology is simply a tool without any inherent political allegiance.

An under-examined aspect of ICT-enabled collective action is the impact of anonymity. A study of note on this topic explains that ICTs are characterized by isolation and anonymity, but somewhat paradoxically, can also facilitate solidarity and collectivization. The ability to act anonymously is obviously a significant advantage for individuals fearing backlash or repercussions for taking part in actions critical of the government.

A critical debate at the center of this topic is whether or not the internet actually facilitates democratic action at all or merely provides the illusion of doing so. A number of scholars argue that technology does in fact facilitate meaningful democratic action. ${ }^{48}$ The impact of modernization and globalization, including the erosion of state borders, the emergence of transnational corporations, and citizen apathy towards official methods of

\footnotetext{
${ }^{47}$ Diamond, "Liberation Technology," 70.

${ }^{48}$ Martha McCaughey and Michael D. Ayers, Cyberactivism: Online Activism in Theory and Practice (London: Routledge, 2003); Wilfred Van de Donk, Cyberprotest: New Media, Citizens and Social Movements (London: Routledge, 2004).
} 
political participation like voting have cleared the way for alternative forms of engagement outside of the mainstream. Technology has also altered the landscape of political action by introducing brand new forms of participation. ${ }^{49}$ Additionally, the use of ICTs has shifted the focus of collective goals to favor single-issue, value driven goals rather than the ideologically-rooted, broad-sweeping social changes of the past. This body of research reveals a fascinating trend in how emerging forms of technology are actually re-shaping the landscape of social movements.

Broadly, the literature has identified three major points at which technology and participation potentially intersect: participation costs, collective identity, and a sense of community.$^{50}$ Participation costs are affected in that ICTs allow for cheaper, more efficient methods of communication between individuals within a group. Collective identity is the concept of group solidarity through shared grievances. This is related to the networking potential of the internet, which enhances the organizational structure of social movements by solidifying loosely structured networks and optimizing the flow of information. ${ }^{51}$ Lastly, a sense of community is derived from individuals connecting through shared interest, goals, or grievances. This sense of community ties into the idea that the internet has emerged as a new public sphere capable of sustaining democratic

\footnotetext{
${ }^{49}$ Ibid.

${ }^{50}$ R. Kelly Garrett, "Protest in an Information Society: A Review of Literature on Social Movements and New ICTs." Information, Communication and Society. 9.2 (2006): 202-224.

${ }^{51}$ Tian Luo, "Grassroots Mobilization of Internet NGO's in China: The Cases of www.1kg.org and ww.geshanghua.org" (paper presented at Fifth International Conference on Information and Communication Technologies and Development, March 12-15 2012, Atlanta, Georgia).
} 
dialogue. ${ }^{52}$ Research has also indicated, somewhat counter intuitively, that activities characterized by isolation and anonymity can actually enhance group attraction. ${ }^{53}$

A major discussion amongst social movement researchers relates to how protest tactics are affected by the use of ICTs. Rapid mobilization, swarming behavior, and the ability to act on multiple fronts simultaneously are all benefits of technologically aided communication. An additional benefit is that the near instantaneous dissemination of information creates transparency and increases the public accountability of elites. ${ }^{54}$ This phenomenon is known as the inverted panopticon, and is especially relevant to populations under authoritarian rule. ${ }^{55}$

Despite the obvious benefits, some researchers caution against an over-reliance on ICTs, stressing that technology is frequently wielded by authoritarian regimes in order to further repress the populace which therefore renders any advances in communication between private citizens moot. The integrity of information transmitted through ICTs has also been called into question by researchers. ${ }^{56}$ False or misconstrued information can be rapidly transmitted through communication networks and deleteriously impact the understanding of critical issues or events connected to social movements. ${ }^{57}$ The effect was apparent in the crack-down following the Iranian election protests during which Twitter became rife with rumors such as "police helicopters were pouring acid and

\footnotetext{
${ }^{52}$ Habermas, The Theory of Communicative Action: The Critique of Functionalist Reason.

${ }^{53}$ Kai Sassenberg and Tom Postmes, "Cognitive and Strategic Processes in Small Groups: Effects of Anonymity of the Self and Anonymity of the Group on Social Influence," British Journal of Social Psychology 41 (2002): 463-480.

54 John Arquilla and David Ronfeldt. The Advent of Netwar (Revisited) (Santa Monica: Rand, 2001).

${ }^{55}$ Michel Foucault, Discipline and punish: the birth of the prison (New York: Pantheon Books, 1977).

56 José Márcio Ayers, "From the Streets to the Internet: the cyber-diffusion of contention." Annals of the American Academy of Political and Social Science 566 (1999): 132-43.

57 Ibid.
} 
boiling water on protesters," a claim that could never be substantiated. ${ }^{58}$ An opposing argument counters this notion by explaining that ICTs can just as easily be used to fact check information and dissipate misinformation as well as the sort of sensationalist apocrypha produced during the Iranian protests. ${ }^{59}$ Essentially, the Iranian example underlines the notion that ICTs are simply a tool capable of producing a wide range of results based on how they are utilized in a given situation.

Another vein of research skeptical of the pro-democratizing power of ICTs states that access to the internet has no significant impact on citizen participation levels. A number of studies observed that political participation rates in the United States have not changed much since 1950 despite major technological advancements. ${ }^{60}$ The cause for this lack of change is rooted in the political-psychological phenomenon that increased exposure to low-cost information cannot enhance human beings' ability to systematically absorb it. While this assertion has broad implications in terms of human understanding of information, his conclusions do not necessarily preclude an increase in accessing and acting on said information.

The body of literature related to ICTs and social movement participation is expansive and diverse in perspectives. The majority of researchers in this group agree that ICTs have altered the landscape of political participation in some shape or form, with the exception of a study that questions the relationship between ICTs and political action. The methods of these studies also varied significantly and included both qualitative and quantitative methods. Previous literature on the topic of social control and

\footnotetext{
${ }^{58}$ Morozov, The Net Delusion: The Dark Side of Internet Freedom, 15.

${ }^{59}$ McCaughey and Ayers, Cyberactivism: Online Activism in Theory and Practice.

${ }^{60}$ Bruce Bimber, "The Internet and Political Mobilization: Research Note on the 1996 Election Season," Social Science Computer Review 16 (1998): 399-401.
} 
communication technology is varied but can generally be divided into the broad themes of whether ICTs strengthen or weaken authoritarian regimes. Advocates of ICTs as tools of regime survival cite how technology strengthens government capabilities for censorship, surveillance, and propaganda. Those in favor of ICTs' pro-democratizing nature explain that technology can undermine autocratic rule by allowing activists to communicate and organize in order to achieve collective goals, in addition to ICTs serving as an alternative press to share criticism of the regime.

In terms of theoretical framework, theories related to social movements and regime transition were most common in the literature. In prior studies, democratic transition theory and authoritarian consolidation theory were popularly used as lenses to clarify the role of ICTs under authoritarian regimes. Some researchers found that communication technologies carried an intrinsic liberalizing effect, while other studies concluded that ICTs could easily be co-opted by the government to stabilize its own rule. Social movement theories, such as collective action theory, were typically employed for projects focused on how successful social movements employed ICTs, but did not address failed movements in equal measure. The following chapter will draw upon the literature to establish a theoretical lens for this particular project. 


\section{CHAPTER III}

\section{THEORY}

The theoretical groundwork of this project seeks to explain why the PRC utilized ICTs as a subtle method of social control to limit freedom of speech and collective action during the 2014 Umbrella Movement. In order to answer this question, a deeper understanding of the PRC's underlying motivation is necessary. Based on related research, authoritarian consolidation theory and the theory of collective action potential were chosen as lenses to better understand different dimensions of the research question at hand.

\section{Authoritarian consolidation}

Authoritarian consolidation theory seeks to explain the nature of how and why certain authoritarian regimes persist while others collapse or transition toward democracy. Traditionally, theories regarding regime change and democratic transition hold that non-democratic regimes are gradually and inevitably gravitating towards democratization. This is largely due to the assumption that authoritarian governments are inherently frail based on fragile legitimacy and dependence on overtly coercive tactics of social control. ${ }^{61}$ A number of authoritarian states, including China, seem to have

\footnotetext{
${ }^{61}$ Andrew J. Nathan. "China's Changing of the Guard: Authoritarian Resilience." Journal of Democracy
} 14, no. 1 (2003): 6. http://muse.jhu.edu/journals/jod/summary/v014/14.1nathan.html 
weathered the "third wave" 62 of democratic change and appear to be growing more stable and complex over time. The relatively nascent authoritarian consolidation theory is emerging from the growing number of scholars interested in how particular regimes have resisted pressure to democratize, despite an overwhelming body of research that asserted democratization was a nearly inevitable global phenomenon.

A core assumption of democratic transition theory is that all autocratic states are gravitating towards the eventual end-goal of democracy. Recent research on the survival of authoritarian regimes has uncovered a blind spot in democratic theories, pointing out that prior theories focused on factors that precipitated change, neglecting to investigate causes that lend stability to autocratic regimes. ${ }^{63}$ This new vein of research tunes into regime strengths, which naturally increase the likelihood of regime stability, rather than searching exclusively for weaknesses which might signal eventual transition. Before further analyzing the root causes of consolidation, we must first answer this question: what is consolidation? Generally, consolidation is defined as a regime's progression toward relative stability. ${ }^{64}$ Although democratic and authoritarian regimes differ in numerous ways, the process of consolidation is actually quite similar for both in that it occurs when a complex system of institutions and rules becomes uncontested. ${ }^{65}$ Ultimately, consolidation theory provides a framework for understanding the factors that contribute to long-term regime stability. Key to regime stability and survival, for both

\footnotetext{
${ }^{62}$ Samuel P. Huntington's concept describing the surge of unprecedented global democratization that began in the mid-1970's.

${ }^{63}$ Thomas Ambrosio, "Beyond the Transition Paradigm: A Research Agenda for Authoritarian Consolidation," Demokratizatsiya 22 (2014): 471-495.

${ }^{64}$ Ibid.

${ }^{65}$ Juan. J Linz, and Alfred Stepan, Problems of Democratic Transition and Consolidation: Southern Europe, South America, and Post-Communist Europe (Baltimore: Johns Hopkins University Press, 1996).
} 
authoritarian and democratic governments alike, is the accomplishment of comprehensive authority, a status that describes a central government's ability to effectively reign in various social and political forces. ${ }^{66}$ While coercion can technically be utilized to accomplish comprehensive authority, any newfound unity will be short-lived as coercive powers tend to rapidly erode regime legitimacy. ${ }^{67}$

Factors influencing authoritarian consolidation are numerous, but can be grouped into four broad categories including: institutional, attitudinal, economic, and external factors. ${ }^{68}$ While all of these factors contribute to regime survival, the institutional aspect was found to be most relevant to social movements and their resulting threat to stability. Regime stability is integrally connected with institutional strength and pervasiveness, and a key factor in regime resilience is the government's capacity to effectively embed itself in office, an endeavor which relies on a careful balance of power between elites, and the perception of legitimacy between elites and on the populace. ${ }^{69}$ Although authoritarian regimes lack the electoral institutions of democracies, it is important to note that leadership change still does occur within autocratic regimes and is not the same as regime change, which indicates systemic upheaval. However, peace between elites is not the only ingredient to stability.

Regime resilience also depends on the regime's ability to manage conflicts between elites and the populace. In democracies, this is achieved through regular elections, universal suffrage, and written constitutions. In autocracies, different

\footnotetext{
${ }^{66}$ Goebel, “The Information Dilemma: How ICT Strengthen or Weaken Authoritarian Rule,” 179. ${ }^{67}$ Ibid.

${ }^{68}$ Ambrosio, "Beyond the Transition Paradigm: A Research Agenda for Authoritarian Consolidation," 474475.

${ }^{69}$ Ibid.
} 
institutions exist to address the demands of the people in order to foster a sense of legitimacy and long-term regime stability. These alternative institutions fulfill the doublebenefit of bolstering regime legitimacy in the eyes of the populace while allowing the regime to remain in complete formal control of policy decisions. ${ }^{70}$ Overall, these institutions are carefully designed with the intent of discouraging collective action. This allows the government to acknowledge a certain degree of criticism while making only minor policy adjustments. Additionally, it provides officials a direct method of monitoring public opinion, which directly benefits the regime by providing insight into the public's thoughts, concerns, and grievances. ${ }^{71}$ Even in authoritarian regimes, it is critical to have conflict resolution systems such as this bridging the interests of the people and the elites. ${ }^{72}$ This system can also work as a pressure valve for social unrest. By framing issues as easily solvable individual complaints, they are not likely to gain inertia and grow into mass discontent.

Some scholars are skeptical of the integrity and effectiveness of these conflict resolution institutions ${ }^{73}$. Rather than representing genuine democratic channels, critics argue that these institutions instead fabricate a false veneer of dialogue between the populace and their leaders, in addition to providing the government a channel for keeping tabs on its citizens and transmitting propaganda. ${ }^{74}$ Studies show that complaints often go unaddressed or unresolved, and that the government is likely using the system as a clever

\footnotetext{
${ }^{70}$ Nathan, "China's Changing of the Guard: Authoritarian Resilience," 14.

${ }^{71}$ Göbel, "The Information Dilemma: How ICT Strengthen or Weaken Authoritarian Rule," 388.

72 Thomas Ambrosio, "Beyond the Transition Paradigm: A Research Agenda for Authoritarian Consolidation," 485.

${ }^{73}$ Nele Noesselt, "Microblogs and the Adaptation of the Chinese Party-State's Governance Strategy," Governance: An International Journal of Policy, Administration, and Institutions 27(30): 444-445.

${ }^{74}$ Göbel, “The Information Dilemma: How ICT Strengthen or Weaken Authoritarian Rule,” 386.
} 
way of monitoring public opinion without any real intention of meaningfully addressing the conflict. ${ }^{75}$

These institutions are significant because they allow the regime a high degree of social control that does not rely on overtly coercive tactics like violence and terror. Coercive power is key to resisting regime change, but if wielded improperly, can signal weakness or even backfire to galvanize opposition movements. ${ }^{76}$ This highlights the importance of carefully calibrated coercion, which aims to neutralize challenges with minimal political fallout. ${ }^{77}$ ICTs enable governments to employ subtler methods of coercion like censorship, surveillance, and digital crowd control, which are less harmful to its public image and legitimacy than violent means of control. Relevant scholarship further argues that consolidation involves the regime learning how to interact with various political and social groups in a non-despotic manner, therefore reducing the risky side-effects associated with blatant coercion. ${ }^{78}$ In terms of why only particular authoritarian regimes, like China and Russia, experience long-term survival while others do not, researchers posit that the quality of the regime itself, rather than regime type, determines regime longevity. ${ }^{79}$ This argument challenges the democratic transition theorists' assumption that all authoritarian regimes are destined to collapse, and opens the door to examining how the qualities and characteristics of a particular regime determine longevity.

\footnotetext{
${ }^{75}$ Zhu and Skoric, "The Role of ICT's in Adaptive and Persistent Authoritarianism: A Study of China at the Administrative Division Level."

${ }^{76}$ Perry, Challenging the Mandate of Heaven: Social Protest and State Power in China.

${ }^{77}$ Cherian George, "Consolidating authoritarian rule: calibrated coercion in Singapore," The Pacific Review 20 (2007): 127-145.

${ }^{78}$ Christian Göbel, “Authoritarian Consolidation,” European Political Science 10 (2011): 176-190.

${ }^{79}$ Goebel, "The Information Dilemma: How ICT Strengthen or Weaken Authoritarian Rule," 388.
} 


\section{Collective action}

The relationship between mass social movements and regime change is well established, and supporting case studies abound from around the globe, including former Eastern Bloc states and, more recently, social movements in the Middle East. Successful authoritarian regimes understand that regime longevity depends on a careful balance of perceived legitimacy and social order.

In social movement research, collective action theory is commonly cited by researchers seeking to determine the causes and facilitating factors of mass collectivization. This particular theory provides a basis for understanding why individuals seek to collectivize in order to achieve certain common goals. Foundational research on collective action theory states that individuals who share common or overlapping interests will collectivize in order to achieve common goals. ${ }^{80}$ Understanding how and why individuals aggregate around a specific cause will provide insight into how the PRC identifies, addresses, and ultimately defuses collectivization.

The innovation of modern communication technology has introduced a new element into social movement dynamic. ICTs can enable group collectivization in societies that lack formal channels of participation, and in some cases can even overcome intentional communication barriers like government censorship programs. The potential for ICTs to enable collective action is an inherent paradox in that a medium characterized by social isolation can facilitate social unity. ${ }^{81}$ The progression of research on the subject has evolved over time, with early researchers arguing that the internet served to alienate

\footnotetext{
${ }^{80}$ Mancur Olson, The Logic of Collective Action: Public goods and the theory of groups (Cambridge: Harvard University Press, 1965).

${ }^{81}$ Suzanne Brunsting and Tom Postmes, "Social Movement Participation in the Digital Age: Predicting offline and online collective action," Small Group Research 33.5 (2002): 525-554.
} 
individuals through the reduction of social cues, while more recent academic investigation has revealed just the opposite. ${ }^{82}$ The depersonalizing effect of internet activities serves to minimize differences between individuals and enhance a sense of group sameness. ${ }^{83}$ Ultimately this phenomenon stems from the idea that social identityor the aspects of an individual's identity derived from group membership — remains potent even in the absence of physical proximity. ${ }^{84}$ Additionally, a formal sense of collective identity is not necessarily a requisite for collective action as long as "imagined solidarity" exists as a unifying force. ${ }^{85}$ The idea of collectivization despite anonymity and individual isolation is important, since authoritarian regimes have long relied on atomization and alienation as strategies to thwart collective action. As a result, autocratic strategies of social control have evolved to rely on more subtle forms of coercion and manipulation online.

The intersection of mobilization and anonymity in relation to social movements is especially relevant to understanding collective behavior in authoritarian states. Some research stresses that activists are increasingly endangered by the content they publish online due to the erosion of privacy. ${ }^{86}$ This is true in the case of Hong Kong, where censorship policies and a fear of legal repercussions often prevent individuals from publicly broadcasting opinions that could be considered subversive or critical of

\footnotetext{
82 Ibid.

${ }^{83}$ Sassenberg and Postmes, "Cognitive and Strategic Processes in Small Groups: Effects of Anonymity of the Self and Anonymity of the Group on Social Influence,"

${ }^{84}$ Russell Spears, Martin Lea, and Stephen Lee, "De-Individuation and Group Polarization in ComputerMediated Communication,” British Journal of Social Psychology 29 (1990): 121-134.

${ }^{85}$ Benedict Anderson, Imagined Communities: Reflections on the Origin and Spread of Nationalism (USA: Courier Companies, 1991); Asef Bayat, "Islamism and Social Movement Theory," Third World Quarterly 26 (2005): 891-908.

${ }^{86}$ Amy Leung, "Anonymity as Identity: Exploring Collective Identity in Anonymous Cyberactivism," International Journal of Technology, Knowledge and Society 9 (2013): 173-184.
} 
government actions ${ }^{87}$ Essentially, communication technologies are eroding the ability of autocratic regimes to maintain a monopoly on information, which in the past was a classic authoritarian strategy for social control.

Research by Manual Castell demonstrates that ICTs increase transparency of information which vastly minimizes "communication-free pockets," resulting in group empowerment and mobilization. Enhanced communication leads to increased visibility of issues in the political sphere which directly stimulates participation in social movements. Through this argument he indicates that technology is capable of fundamentally modifying social structures ${ }^{88}$ Castell's research also makes an important distinction: ICTs are a potent medium for change but not a cause. Extending Castell's argument to the research project at hand, ICTs will be treated as a non-causal medium while examining their role in a series of recent protests in Hong Kong.

The PRC is well aware of how ICTs can enable unsanctioned channels of communication between individuals, and the potential damage that the resulting social movements can cause to the regime. In response to the threat of collective action, "the stated perspective of the Chinese government is that limitations on horizontal communications is a legitimate and effective action designed to protect its people." ${ }^{89} \mathrm{In}$ other words, the Chinese government views collective action as a direct threat to social and political stability and works to identify and defuse social movements before they can gain any serious momentum. The overlapping lenses of the theory of collective action

\footnotetext{
${ }^{87}$ Lee and Chan, "Professionalism, Political Orientation, and Perceived Self-Censorship: A Survey Study of Hong Kong Journalists."

${ }^{88}$ Manuel Castells, Rise of the Network Society: The Information Age: Economy, Society, and Culture Volume I. (Hoboken: Wiley-Blackwell, 2009).

${ }^{89}$ King, Pan, and Roberts, "How Censorship in China Allows Government Criticism but Silences Collective Expression," 326-343.
} 
potential and authoritarian consolidation theory will shed light on how the PRC approaches ICTs in regards to regime stability.

The theory of collective action potential originally appeared in a 2012 research article by Gary King, Jennifer Pan, and Margaret Roberts. The article focuses on China's intricate censorship paradigm and posits that the paradigm's ultimate goal is not to simply block controversial messages, but to diffuse the larger threat of collective action. King's research utilizes a slight reframing of collective action theory that specifically focuses on the causes of collective action in relation to the preventative measures the government may take to diffuse it. This is based on the Chinese government's perspective that unsanctioned mass action of any sort threatens the order and safety of society. Since China experiences a high number of "mass incidents" each year, reporting over 180,000 in 2010 alone,${ }^{90}$ controlling collective action is a major concern of the communist regime. ${ }^{91}$ In fact, the PRC takes the issue so seriously that local officials are evaluated inpart by the frequency of collective action in their localities. ${ }^{92}$

The theories explored in this section will provide an investigative lens for two important aspects of this project. Authoritarian consolidation theory establishes a framework for understanding how and why the PRC may utilize ICTs to strengthen its power and mitigate external threats like social movements. Collection action theory provides an in-depth understanding of the nature of social movements and how ICTs can

\footnotetext{
${ }^{91}$ Edward Wong, "China's Growth Slows, and Its Political Model Shows Limits." New York Times, May 10, 2012. http://www.nytimes.com/2012/05/11/world/asia/chinas-unique-economic-model-gets-newscrutiny.html?_r=1

${ }^{92}$ Maria Edin, "State Capacity and Local agent Control in China: CPP Cadre Management from a Township Perspective." China Quarterly 173 (2003):35-52.
} 
be harnessed by activists to rapidly disseminate information and organize to achieve collective goals, both of which threaten the PRC. Now that a theoretical backing has been established, the next section will construct a research design for the specific question at hand. 


\section{CHAPTER IV RESEARCH DESIGN AND METHODS}

The methods selected for this project will shed light on the question: Why did the PRC utilize ICTs as a subtle means to limit freedom of speech and collective action during the Umbrella Movement? This section will discuss the broad structure underlying this project's investigation, including the case study method, the illustrative analytic approach, the specific variables under scrutiny, and data-collection methods.

A core assumption of this study is that the PRC is motivated by a drive to remain in power, and to not allow its political influence to erode to the point that substantive democratic reforms are made in Hong Kong. Based on a thorough investigation of the Chinese government's extensive usage of internet censorship and surveillance, this study also assumes that the PRC is willing to manipulate ICTs in ways that align with its own goal of self-preservation. This study will focus on several key methods the PRC employed in order use ICTs to its own advantage, including censorship and surveillance. In terms of delimitations, the analysis will be limited to the mass protest known as the Umbrella Movement which occurred in Hong Kong during September and December 2014.

Since discerning how ICTs were utilized during the Umbrella Movement hinges on a full understanding of key contextual and historical conditions, the case study was selected as the most appropriate method for this particular research question. In an 
instructional publication on case study research, Robert Yin explains that the method is ideal for research questions that focus on observable phenomenon grounded in a realworld context. ${ }^{93}$ Additionally, case studies are ideal for tackling the "how" and "why" behind complex contemporary phenomena.

Another strength of the case study lies in its ability to synthesize multiple sources of evidence into a multi-dimensional framework of analysis. This thesis will draw from a number of sources in order to establish a comprehensive picture of events and to ensure accuracy of evidence. Specifically, news articles, reported interviews with demonstrators, and blog entries from the time frame of the protest will be used to establish a framework for the events. Since ICTs allowed for activists to communicate and upload information in real-time, a plethora of first-hand information exists documenting the protests. Government usage of ICTs will be measured through data regarding censorship and surveillance. Specifically, censorship can be gauged by the frequency of deleted internet posts containing protest-related keywords, content deletion requests, and blocked websites. Surveillance is primarily measured through the frequency of government requests for user information, anecdotal evidence from activists, and information regarding cyber-spying. Activist participation will be gauged through protest turnout data, internet and mobile phone usage rates, and the number of downloads for "off the grid" mobile phone app FireChat.

Since the PRC did not publically advertise the actions it took against antigovernment protestors, and freedom of speech in general, information from a series of sources will be compiled in the analysis section to shed light on specifically how the

${ }^{93}$ Robert Yin, Case Study Research: Design and Methods (Thousand Oaks: Sage, 2002). 
government acted on the demonstrations. Information referencing the protests from Xinhua, the official state newspaper, and state-controlled China Central Television can be used to gauge the PRC's public reaction to the events. Additionally, data collected from select blogs and social media platforms reveal that certain keywords related to the situation in Hong Kong were systematically censored.

This research project will draw upon two theoretical approaches to discuss the results of the collected data: autocratic consolidation theory, and collective action theory. The data compiled in the case study will be approached through the illustrative strategy, which involves using an analytical tool for interpreting and clarifying a specific historical event. For this project, autocratic consolidation theory will provide an interpretative lens for the research question at hand. This theory was selected because it seeks to explain how authoritarian regimes become embedded in societies through social, institutional, or political factors. Additionally, a theory regarding collective action will be used in a supporting role in order to establish an understanding of mobilization and social movements. While the protestors are not the primary focus of this study, their motives, methods, and strategies, particularly as they pertain to ICTs, provide critical context for the analysis. 


\section{CHAPTER V \\ BACKGROUND AND CONTEXT}

Since case studies provide a petri dish analysis of a real-life event, and these events do not take place in a vacuum, it is critical to provide context in order not to arrive at a one-sided, flawed, or overly simplistic conclusion. This chapter will ground the role of ICTs within the 2014 Umbrella Movement in Hong Kong with the goal of shedding light on the various factors that led to the PRC intervening in and ultimately containing the pro-democracy movement.

Hong Kong's Umbrella Protest is the most recent manifestation of the stark social, political, and cultural differences between the territory and Mainland China. Hong Kong's divergent course began in 1842, when Great Britain acquired the peninsula as a colony in the aftermath of the First Opium War. The British negotiated a ninety-nine year lease with China, during which the colonial government sought to transform Hong Kong into a major trading hub. Although the original treaty called for a ninety-nine year lease of the territory, in reality Great Britain held on to Hong Kong for 150 years, which resulted in a century-and-a-half of divergent social, economic, and political development from the rest of China. As Hong Kong's colonial occupation came to an end, the British and Chinese negotiated terms for the territory's transfer, including the creation of a miniconstitution called the Basic Law. Hong Kong's constitution outlines the territory's governmental structure and the rights of its citizens, including the rights to free 
expression and assembly. ${ }^{94}$ Of particular interest is the Basic Law's stipulation that its "ultimate aim is the selection of the Chief Executive by universal suffrage upon nomination by a broadly representative nominating committee in accordance with democratic procedures." 95

Since Hong Kong was transferred back to China in 1997, there have been dozens of protests criticizing the Mainland's governance policies. Hong Kongers' growing sense of dissatisfaction towards Beijing's ability to manage the territory was solidified in a poll that revealed the highest levels of disapproval in a decade. ${ }^{96}$ Of Hong Kong residents between the ages of 21 and 29, 82 percent registered disapproval. ${ }^{97}$ The nature of the protests indicates a schism in the expectations that Hong Kong and China each have for the territory's future. Hong Kong expects a progressively more liberal, Western-style democracy which upholds rule of law as well as freedom of speech, association, and universal suffrage. China expects to eventually assimilate Hong Kong into the Mainland's authoritarian administration, while providing the territory with a marginal degree of social and political freedom beyond what the Mainland enjoys.

Under the current One Country, Two Systems policy, Hong Kong is legally guaranteed certain liberties, such as freedom of speech and association. ${ }^{98}$ However, there appears to be a widening grey zone between law and practice where the liberties of residents of Hong Kong are not as clear cut as the constitutional language implies.

\footnotetext{
94 “Chapter III: Fundamental Rights and Duties of the Residents," Last modified July 13, 2012, http://www.basiclaw.gov.hk/en/basiclawtext/chapter_3.html.

95 Gordon C. Chang, "The Hong Kong Moment: Trouble on China's Periphery,” World Affairs 177 (2015): 14-15.

${ }^{96}$ Michael Forsythe, Chris Buckley, and Alan Wong. "In Hong Kong, an Unofficial Election Draws Beijing's Ire.” The New York Times. June 30, 2014.

97 Ibid.

98 "Chapter III: Fundamental Rights and Duties of the Residents," Last modified July 13, 2012, http://www.basiclaw.gov.hk/en/basiclawtext/chapter_3.html.
} 
Particularly, human rights issues such as the violation of free speech and assembly, privacy rights, and covert surveillance are of concern. Although the legal rights outlined in Hong Kong's current constitution are guaranteed until 2047, at which point the territory will be fully transferred over to the People's Republic of China, some residents of Hong Kong feel their freedoms are already slipping away as Mainland China gains economic and political momentum.

A prime example of this authoritarian encroachment occurred in 2003 when, under pressure from officials in Beijing, Hong Kong's legislature attempted to quickly and quietly pass an anti-sedition law that would allow for the warrantless search of individuals or groups deemed subversive, a crime which could carry a life-time prison sentence. People in Hong Kong were particularly alarmed by the broad, ambiguous definition of "subversive" activity and the apparent disregard for due process. As a result, Hong Kong erupted into the largest protests in the territory's history, with over half a million people taking to the streets. Due to the massive outcry, the law was ultimately shelved. ${ }^{99}$ A similar incident played out a decade later in 2012, when a Beijing-backed law to introduce a patriotic education program in Hong Kong schools once again drew the public's ire. The government explained that the classes were necessary to cultivate a sense of shared national identity with China, but critics accused the program of being an overt attempt at indoctrinating Hong Kong's youth with pro-communist ideals. After weeks of protests, the government finally compromised by making the classes optional. ${ }^{100}$ Considering Hong Kongers lack a formal democratic channel with the

\footnotetext{
99 "Huge Protest Fills HK Streets," CNN.com, last modified July 2, 2003. http://edition.cnn.com/2003/WORLD/asiapcf/east/07/01/hk.protest/

100 "Hong Kong backs down over Chinese patriotism classes.” BBC News, September 8, 2012. http://www.bbc.com/news/world-asia-china-19529867
} 
Mainland, and that authoritarian China is not legally bound to appease popular demands, Hong Kong's protests have been surprisingly effective in blocking Beijing's creeping legal advancements.

Sparks began to fly once more in early 2014 as China and Hong Kong's administrations began hashing out details regarding election reforms for the territory. One of the reforms promised to Hong Kong was universal suffrage by 2017. In other words, residents of Hong Kong would be able to vote in open, free elections on who would become the territory's next Executive leader. In order to show Hong Kong's commitment to democracy, the civic group Occupy Central organized a nation-wide unofficial referendum regarding the future of Hong Kong's elections. Representatives of the PRC immediately decried the referendum, stating in Xinhua, the official news outlet, that the referendum was both invalid and illegal. ${ }^{101}$ Another official remarked, "No plot by a socalled 'civil disobedience movement' to force the central government to make concessions on principles and on its bottom line stands any chance of success."102 Beijing's stance was clear. In addition to the official disapproval of the PRC, the referendum was also plagued by cyber-attacks which temporarily shut down voting. The election platform was struck by a sophisticated denial of service (DDOS) attack described as "one of the largest and most persistent" of its kind. ${ }^{103}$ The referendum organizers blamed hackers supported by the Chinese authorities, but the origin of the digital attack

\footnotetext{
${ }^{101}$ Michael Forsythe, Chris Buckley, and Alan Wong, "In Hong Kong, an Unofficial Election Draws Beijing's Ire," The New York Times, June 30, 2014. 102 Ibid.

${ }^{103}$ Alan Wong, "Cyberattack on Hong Kong Vote was Among Largest Ever, Security Chief Says,” The New York Times. June 21, 2014.
} 
was never officially determined. However, despite the setbacks, over half a million participants were able to cast symbolic ballots. ${ }^{104}$

Amid rising tensions over Hong Kong election reforms, Beijing released a white paper reasserting its authority and comprehensive jurisdiction over the territory. ${ }^{105}$ According to Chinese authorities, the statement was released in order to clarify the power-structure between Hong Kong and China, and to dispel any misunderstandings regarding the current One Country, Two Systems policy. The doctrine stated that "Hong Kong can maintain prosperity and stability for a long time only when the policy of 'onecountry, two systems' is fully understood and implemented," and additionally stressed the importance of patriotism toward the central government. ${ }^{106}$ Alan Leong, a Hong Long legislator and head of the pro-democratic Civic Party, explained that the statement was unprecedented because the PRC had never before asserted that Hong Kong's legislative structure should prioritize the needs of the Mainland. ${ }^{107}$ The statement also appeared to be a turning point for Hong Kong's pro-democracy advocates, with some being invigorated by what they perceived as an attack on Hong Kong's liberties, while others became disheartened and doubtful of the territory's future.

The catalyst of the Umbrella Movement was the announcement on August 31, 2014, that the PRC's electoral reforms would come in the form of a popular election between candidates pre-chosen by officials in Beijing. In other words, the people of Hong

\footnotetext{
104 Ibid.

105 Calum MacLeod, “Cyberattacks Disrupt Hong Kong Democracy Drive,” USA Today. June 19, 2014. http://www.usatoday.com/story/news/world/2014/06/19/hong-kong-democracy-drive/10841333/

106 “China Media: White Paper on Hong Kong,” BBC.com, last modified June 11, 2014. http://www.bbc.com/news/world-asia-china-27790302

107 Tim Hume, "Alarm in Hong Kong at Chinese White Paper Affirming Beijing Control," CNN. June 13, 2014. http://www.cnn.com/2014/06/11/world/asia/hong-kong-beijing-two-systems-paper/
} 
Kong could select its Chief Executive, but Beijing would choose the candidates. Prodemocracy advocates ridiculed the plan, arguing that it made a mockery of universal suffrage and gutted the democratic principle of "one person, one vote." A detailed breakdown of the ensuing events will be covered in the next section.

\section{Timeline of Events}

This project will address the reasons for which ICTs were used by the PRC in order to limit freedom of speech and collective action during the Umbrella Movement which began in Hong Kong in September 2014 and evolved into a seventy-nine day occupation of the city's financial district. The burst of protests that occurred in late summer 2014 are over, but the struggle of pro-democratic activists to see their dream of universal suffrage realized is still technically ongoing. The conclusion chapter will provide a progress update on the issue of universal suffrage, as well as cover related events which have taken place since the 2014 Umbrella protests.

On September 22, 2014, the first official protest of the Umbrella Movement began when members of the student group Scholarism staged a week long class boycott demanding that the PRC allow Hong Kong to hold open nominations for Chief Executive candidates. Tens of thousands of protestors joined the movement in the ensuing days, and on September 26, students stormed Hong Kong's Civic Square, a public space abutting a number of government buildings. Police responded with tear gas and arrested dozens of demonstrators, including key student leaders. This marked a turning point in the movement because it was the first time police demonstrated force against the peaceful protestors. While the actions of the authorities aimed to slow down the movement, 
activists were galvanized by what they perceived as an attack on their constitutional freedoms. The image of a demonstrator wielding an umbrella against a thick cloud of tear gas spread like wildfire across social media and became a symbol for the movement.

Despite the movement's growing inertia in the face of government pushback, activists were dealt a major blow when days later an organized gang disrupted the peaceful demonstrations. A violent mob of masked attackers tore through the demonstration, attacking activists and slashing tents and banners in an attempt to incite fear and chaos. After arresting 19 attackers, police confirmed that eight had ties to a local organized crime group known as the Triad. The attacks sparked paranoia amongst activists and resulted in accusations that the thugs were paid by the government to disrupt the demonstration. ${ }^{108}$ Hong Kong officials similarly accused the PRC of orchestrating terror to disperse protestors and condemned the use of physical force against peaceful activists. ${ }^{109}$ The territory's pro-Beijing secretary of state launched back that the accusations were fabricated and unfair, but encouraged the activists to disperse before further violence occurred. ${ }^{110}$ Ultimately the claims could neither be officially confirmed nor disproven, and the event became another fracture between the government and the populace, marked by suspicion and distrust. The final, major event of the Umbrella protest was the Peace Rally on October $4 .{ }^{111}$ Tens of thousands of demonstrators converged in Hong Kong's government district in defiance of the recent attacks against

\footnotetext{
${ }^{108}$ Rishi Iyengar, "Hong Kong Government Accused of Using Triads to Attack Student Protestors," Time. October 4, 2014

${ }^{109}$ Chris Buckley, Austin Ramzy, and Edward Wong. "Violence Erupts in Hong Kong as Protestors are Assaulted." The New York Times. October 3, 2014. http://www.nytimes.com/2014/10/04/world/asia/hongkong-protests.html

${ }^{110}$ Iyengar, "Hong Kong Government Accused of Using Triads to Attack Student Protestors."

111 “Hong Kong Protestors Mass for Peace Rally," Aljazeera.com, last modified October 4, 2014. http://www.aljazeera.com/news/asia-pacific/2014/10/hong-kong-protesters-mass-peace-rally201410415640966924.html
} 
protestors, and in order to demonstrate their commitment to universal suffrage despite government pushback.

Role of ICTs in the Umbrella Movement

Based on evidence gathered about the protests, this project found that the PRC utilized ICTs to limit activist dialogue and collective action through censorship and surveillance. This section is broken into two sub-sections which explore specific methods the PRC utilized in order to maintain social control, and will also include some reference to how activists likewise utilized ICTs in attempts to achieve their own goals. This will ensure a balanced, full-picture analysis of the event.

\section{Censorship}

ICTs have formed the backbone of China's censorship program since the internet was first adopted by the country in $1994 .{ }^{112}$ Over the years, the censorship program has become more sophisticated and has expanded to block dozens of websites and thousands of forbidden terms. Recent research suggests that the goal of such an initiative is not to simply halt digitally-based political dialogue, but to actively search for signs of collective action potential, clip social ties, and therefore disrupt or mitigate the impact of these budding movements. ${ }^{113}$

\footnotetext{
112 Jaime A. FlorCruz and Lucrezia Seu, "From snail mail to 4g, China celebrates 20 years of Internet connectivity," CNN. April 23, 2014. http://www.cnn.com/2014/04/23/world/asia/china-internet-20thanniversary/

${ }^{113}$ King, Pan, and Roberts, "How Censorship in China Allows Government Criticism but Silences Collective Expression,"326-343; Perry, Challenging the Mandate of Heaven: Social Protest and State Power in China (New York: M.E. Sharpe, 2002).
} 
From the start of the Umbrella Movement, activists very openly and actively utilized ICTs as tools to plan, organize, and execute actions towards achieving collective goals. Social media platforms and texting apps were particularly popular. With services like Whatsapp and Firechat, individuals could mobilize their friends and acquaintances to join them at protest sites as easily as asking them out to dinner. ${ }^{114}$ Activists also harnessed digital technology as a launch pad for broad calls to action and appeals for international support. A video by student activist Glacier Kwong titled "Please Help Hong Kong," was re-posted over a million times in the early days of the movement. ${ }^{115}$ This type of widespread international attention is potent because it can bolster activists and encourage new participants to join. ${ }^{116}$

Evidence from the Umbrella Movement shows that PRC censors were actively engaged in minimizing the digital impact of the movement. Censorship of search terms related to the protests, deletion of related blog posts and images, and blocking platforms like Instagram were all techniques the PRC utilized to disrupt communication both between protestors, and between activists and the outside world. In addition to using ICTs to stem collective action, PRC officials are also aware of the internet's capacity to serve as an alternative press. Since the PRC relies on a single, state-driven narrative, sources of alternative, conflicting information can be highly problematic. As a result, the PRC relied on ICT-based censorship initiatives to diffuse collection action and curtail the spread of information related to the protests.

\footnotetext{
${ }^{114}$ Emily Parker, "Social Media and Hong Kong Protests,” The New York Times. October 1, 2014. http://www.newyorker.com/tech/elements/social-media-hong-kong-protests

${ }^{115}$ Kristie Lu Stout, “Hong Kong's 'Umbrella' protest: One year on, what has changed?" CNN, September 28, 2015. http://www.cnn.com/2015/09/27/asia/hong-kong-protests-one-year-later/

116 Parker, "Social Media and Hong Kong Protests."
} 
Programs like the Hong Kong Transparency Report have actively tracked censorship and other evidence of violations of free speech for years. Reports showed a major increase in censorship activity during 2014. Between September and December 2014, the most active months of the Umbrella Movement, Hong Kong police made 101 demands for content deletion to various websites. In comparison, a total of 94 requests were made during the four previous years combined. Observers from Hong Kong's academic community indicated that the way law enforcement demanded the removal of content revealed potential abuse of power and lack of transparency. ${ }^{117}$

To internet users, the dramatic spike in censorship was apparent as blog entries containing key words related to the unrest in Hong Kong rapidly disappeared. The University of Hong Kong's Weiboscope censorship-monitoring project reported a massive spike in deleted posts during the week the protests began. At its peak, over 150 per 10,000 posts were being erased, with the term "Hong Kong" being the most widely deleted. ${ }^{118}$ Interestingly, the term "Hong Kong protests" was not censored, and in fact rapidly became one of the most popularly searched terms. However, search results yielded only a list of carefully curated pro-government results, indicating that dialoguesteering was likely taking place. ${ }^{119}$

Users of Sina Weibo, a social media platform similar to Twitter popular throughout China and Hong Kong, reported over 20 blocked terms including "Occupy

\footnotetext{
${ }^{117}$ Bryan Harris, "Surge in web posts taken down by Hong Kong police sparks censorship fear," South China Morning Post. February 15, 2015, http://www.scmp.com/news/hong-kong/article/1713551/hongkong-police-pulled-down-more-web-content-last-four-months.

${ }^{118}$ Emma Woollacott, "Can China's Social Media Censorship Keep the Lid on Hong Kong Protests?" Forbes, September 29, 2014, http://www.forbes.com/sites/emmawoollacott/2014/09/29/can-chinas-socialmedia-censorship-keep-the-lid-on-hong-kong-protests/. ${ }^{119}$ Ibid.
} 
Central" (an alternative name for the Umbrella Movement), the names of key student leaders, protest sites such as the city's Admiralty government district, and the names of participating student groups. Additionally, search terms containing "Hong Kong" followed by words like "student strike," "tear gas," “open fire," and "disobey orders" were also blocked. Phrases implying support of the movement, including "Go Hong Kong" and "Today we are all Hong Kongers" were similarly banned. ${ }^{120}$ The largest spike in censorship activity occurring on and just after September 28, the day that riot police took action against Hong Kong protestors and made several dozen arrests. On the same date, Instagram was blocked after activists began uploading pictures of clashes with police, with users receiving the error message "Cannot refresh stream." The impetus of the censorship was clear: thanks to social media, Beijing realized it was under the world's microscope. ${ }^{121}$ Situations like this reveal the inherent duality of ICTs: Web-based visibility meant that Beijing's hands were tied in terms of blatant physical action it could take against demonstrators, but ICTs also allowed the government to rely more heavily on subtler methods of control like censorship and the surveillance of activists.

\section{Surveillance}

Surveillance is another technique of social control commonly utilized by the Chinese government. Unlike censorship, surveillance can be very difficult to detect and is often not initially apparent to the individuals being monitored. For these reasons, measurable data related to surveillance was difficult to find, and most evidence was

\footnotetext{
${ }^{120}$ Anne Henochowicz, "Sensitive Words: Hong Kong Protests (Updated)," China Digital Times. September 29, 2014, https://chinadigitaltimes.net/2014/09/sensitive-words-hong-kong-protests/ ${ }^{121}$ Ellie Ng, "Hong Kong Activists Fear State Snooping," Foreign Policy, December 3, 2014, http://foreignpolicy.com/2014/12/03/hong-kong-activists-fear-state-snooping/
} 
anecdotal. That being said, in the year since the Hong Kong Umbrella Protests took place, some evidence of the surveillance of activists, movement-sympathizers, and other pro-democracy individuals has emerged. Based on evidence and accounts from activists, Hong Kong police used a blend of ICT-based surveillance and more traditional methods like physically shadowing activists. ${ }^{122}$

Phone tapping has a long history in Hong Kong, and reports of monitoring prodemocracy advocates and Mainland defectors stretch back to the late 1990's. Legislation introduced in 2006 was meant to regulate phone surveillance, but anecdotes from longtime activists reveal that the practice has far from vanished. ${ }^{123}$ Among democracy supporters, reports of suspicious phone activity, including clicking, echoes, dropped calls, garbled voices, and muffled voices speaking Mandarin are common. ${ }^{124} \mathrm{~A}$ founding member of a leading pro-democracy organization in Hong Kong remarked, "My phone was tapped for the first time in 1989. For years, I'd hear strange clicking sounds in my calls. It's started again in the recent years as I prepared for Occupy Central." ${ }^{125}$ Dmitri Alperovitch, co-founder of an American cybersecurity company, closely monitored the situation in Hong Kong. "If you're using a cellphone or landline in Hong Kong and you're one of the protestors, you should absolutely expect that your phone calls are being listened to by the Chinese authorities. I would advise them to be paranoid." 126

\footnotetext{
${ }^{122}$ Ibid.

${ }^{123} \mathrm{Ng}$, "Hong Kong Activists Fear State Snooping."

${ }^{124}$ Suzanne Sataline, "Hong Kong activists fear they are being monitored by Beijing." The Guardian. December 14, 2014. http://www.theguardian.com/world/2014/dec/14/hong-kong-activists-beijing-chinesespying-pro-democracy ${ }^{125} \mathrm{Ng}$, "Hong Kong Activists Fear State Snooping."

${ }^{126}$ Sataline, "Hong Kong activists fear they are being monitored by Beijing."
} 
Although there were numerous reports and allegations of phone tapping, the vast majority of evidence is anecdotal, and no concrete data exists to gage the frequency which it occurred. However, internet-based surveillance was slightly less elusive and more quantifiable than phone-based techniques. During the Umbrella movement, at least one Beijing-linked spy ring was discovered by international cyber-security companies. The spy ring, which was referred to as Deep Panda, was found to have covertly gained access to computer networks of both pro-democracy activists and an affiliated political party known for its pro-suffrage platform. Deep Panda's cyber-spies were able to infiltrate users' computers and smart phones through a malware virus. By hijacking someone's contact list, Deep Panda could send out a fake message which appeared to be from a friend, but when the message was opened, a virus was installed on the device which could then collect emails, text messages, and eavesdrop on phone conversations. Spies could also download the contact list off the infected device, and the cycle would begin all over again as new spyware infected messages were sent out. ${ }^{127}$ Deep Panda, or a similar cyber spy-ring, is also thought to be responsible for publically leaking emails and files from several of Hong Kong's high-profile democracy activists.

In the year of the protests, police made 4,234 requests for the personal information of online users including email and IP addresses. ${ }^{128}$ Only a small number of these were issued under court order. While this may seem startling, Hong Kong's legal framework has been shaped in such a way that residents are not adequately protected from online surveillance. Due to a legal loophole, police surveillance via phone, fax, or mail must be approved by a judge in the interest of public security or crime prevention,

\footnotetext{
127 Ibid.

${ }^{128}$ Harris, "Surge in web posts taken down by Hong Kong police sparks censorship fear."
} 
but the law does not cover online surveillance. Additionally, the language of the law itself is quite vague. Jennifer Zhang, a researcher at University of Hong Kong, explains that "The only law that protects user privacy, the Personal Data (Privacy) Ordinance, is very vague in this regard. It allows police to request user information from service providers for a very simple and general 'criminal prevention' purpose." ${ }^{\text {"29 }}$ For the tech-savvy, surveillance was not necessarily an insurmountable threat. Umbrella activists, concerned about police snooping, utilized off-the-grid mobile phone apps like FireChat to communicate anonymously. FireChat was originally designed to be used at music festivals and allows mobile phone users to connect directly to one another without connecting to the internet. Since users were at no point connected to the internet, they left no digital fingerprint, and their user information could not be traced by authorities.

Activists were able to plan, coordinate, share information, and encourage others to join without fear of reprisals. The app was immensely popular with protestors. Data reveals that it was downloaded over 500,000 times in the first two weeks of the protest, recorded over 1.6 million chatrooms, and 10.2 million chat sessions. ${ }^{130}$ In a region like Hong Kong, which boasts a cell phone usership rate of over 200 percent (roughly two phones per person), an anonymous chat app is an immensely powerful communication tool. ${ }^{131}$

\footnotetext{
${ }^{129}$ Ibid.

${ }^{130}$ Peter Shadbolt, "FireChat in Hong Kong: How an app tapped its way into the protests," CNN, October 16, 2014. http://www.cnn.com/2014/10/16/tech/mobile/tomorrow-transformed-firechat/

131 "Key Communications Statistics." Last modified October 23, 2015.

http://www.ofca.gov.hk/en/media_focus/data_statistics/key_stat/
} 


\section{CHAPTER VI}

\section{ANALYSIS}

Communication technology played a central role in the struggle between Hong Kong activists and the Mainland government during the 2014 Umbrella Movement. Based on the evidence, this study found that the PRC was indeed using ICTs to limit the flow of information and minimize collective action potential related to Hong Kong's prodemocracy Umbrella movement. The gathered data centered on instances of censorship and surveillance that the PRC engaged in during the protest.

The PRC's usage of censorship during the protest is well-documented. Evidence of censorship included prohibited search terms, content deletion, and blocked websites. Reasons for this activity, according to the theoretical framework, are two-fold: In the interest of self-preservation, the PRC is driven to limit the transmission of politically sensitive information, in addition to taking a special interest in information that could catalyze into collective action. These methods were clear in the way the PRC sterilized blogs and websites during the time period of the protests. The deletion of protest-specific content and keywords reveals that the PRC took an active role in attempting to minimize the digital impact of the event. By focusing their censorship efforts on certain strategic keywords, such as the names of well-known movement leaders and particular demonstrations, the PRC was attempting to make it difficult for would-be participants to mobilize at particular protest sites. These actions are supported by the theoretical 
framework's expectation that China, while attempting to censor all politically sensitive content, would focus on content that could mobilize collective action. ${ }^{132}$ The sheer rise in censorship frequency is also indicative. Although the PRC routinely engages in web censorship, the time period of the protests experienced a massive spike in content deletion, indicating the Umbrella movement was a high priority for the PRC. In this case, PRC censors launched a broad drag-net for politically sensitive content related to Hong Kong's struggle for democracy, but specifically focused on protest-specific keywords.

Surveillance was also employed by the PRC during the protests, but evidence tended to be more anecdotal in nature with the exception of the frequency of police requests for user information and the discovery of the Deep Panda cyber-spy network. The scarcity of concrete evidence is not altogether surprising since surveillance falls squarely into the second generation of social control, meaning techniques used to monitor civilian activity are more subtle than direct censorship. The PRC, aware of the negative impact that illegally monitoring citizens would have on their legitimacy, knows that subtlety is key for regime preservation. As stated in the literature about authoritarian consolidation, even autocratic regimes have to rely on a carefully maintained sense of legitimacy in order to remain in power. The usage of surveillance ties into the need for subtle methods of social control as highlighted in authoritarian consolidation theory. While certain instances of surveillance are documented, overall data is limited, so it is admittedly difficult to discern the exact level of the PRC's direct involvement from paranoia amongst activists.

\footnotetext{
${ }^{132}$ King, Pan, and Roberts, "How Censorship in China Allows Government Criticism but Silences Collective Expression,” 326-343.
} 
In summary, the evidence gathered from the Umbrella Movement supports major components of both the theories of authoritarian consolidation and collective action potential. Authoritarian consolidation theory explains that regimes survive through subtle social coercion. This is supported by evidence of the censorship of protest-related key words, the promotion of patriotic content, and the surveillance and intimidation of activists. Together, these techniques work to steer the public perception of the events while simultaneously minimizing their digital impact. As theory predicted, the PRC used ICTs to employ subtle mechanism of social control with the goal of maintaining the delicate balance between power consolidation and perceptions of legitimacy.

The PRC's approach to coercive tactics against unrest in the Mainland is wellillustrated by a case in 2009 when the Chinese government instituted an internet ban to the province of Xinjiang after a period of rioting, leaving seven million users without access to the Net for ten months. The government justified the ban by explaining that the riots were organized using the internet and mobile phones. ${ }^{133}$ Xinjiang's full internet ban is an extreme example of how elites partner to control access, but subtler, more complex systems are at work on a daily basis throughout China. Major internet service providers and social media platforms are complicit with government censorship programs. An editor of a popular Chinese micro-blogging website Sina.com published a blog post detailing the company's elaborate censorship scheme. ${ }^{134}$ A number of other popular social media websites share similar programs, and according to anonymous testimonies from their employees, are under "direct pressure from Chinese internet authorities to

\footnotetext{
${ }^{133}$ Chris Hogg, "China restores Xinjiang internet," BBC News, May14, 2010. http://news.bbc.co.uk/2/hi/8682145.stm.

${ }^{134}$ Johnathon Ansfield, "China Tests New Controls on Twitter-style Services," The New York Times, (New York, NY) July 16, 2010.
} 
bolster their systems for monitoring content." ${ }^{\text {135 }}$ While the PRC did not go as far as a full internet shutdown in Hong Kong, activists were fearful enough of the prospect that thousands flocked to off-grid apps like FireChat which would allow them to maintain communication in the event of a shutdown. ${ }^{136}$ Additionally, the Xinjiang case illustrates that the PRC was comfortable employing openly repressive tactics on the Mainland but not in Hong Kong.

In addition to substantiating the impact of coercion on regime legitimacy, the social upheaval of the Umbrella protests also sheds light on the PRC's progress towards regime resilience, another key factor in long-term regime survival. Prior research indicates that in the absence of formal democratic institutions, authoritarian governments often establish alternative channels of participation to address citizen concerns or at least create the illusion of doing so. ${ }^{137}$ According to authoritarian consolidation theory, regimes lacking both formal and informal institutions through which the populace can vent their opinions, complaints, and concerns, will rapidly lose legitimacy. ${ }^{138}$

In Mainland China, local government agencies were created to "absorb and process demands, expand the consultative capacities of their systems, give a stake in the system to various sections of their populations, and perhaps preempt demands for more far-reaching and anti-systemic change." ${ }^{\prime 1}$ For example, many Chinese localities also employ e-governance platforms, where citizens can file concerns online. However, these concerns often go unaddressed by the local authorities, and instead offer a thin veneer of

\footnotetext{
${ }^{135}$ Ibid.

${ }^{136}$ Micha Benoliel, interviewed by Laure Nouraout, Global Editor's Network, October 8, 2014.

${ }^{137}$ Göbel, "Authoritarian Consolidation," 176-190; Nathan, "China's Changing of the Guard: Authoritarian Resilience," 14.

${ }^{138}$ Nathan, "China's Changing of the Guard: Authoritarian Resilience," 14.
} 
political participation. E-governance platforms cannot address large or systemic issues, but can target small problems like petty corruption or damaged urban infrastructure, the results of which, if addressed, are tangibly visible to the populace and strengthen the perception that the government is indeed responsive to citizen demands. ${ }^{139}$ ICTs have become such a popular platform that the PRC actually encourages departments and officials to set up micro-blogs in a further effort to expand online presence and steer digital political discourse. Between January 2011 and December 2012, the number of official blogs swelled from less than 1,000 to $130,000 .{ }^{140}$

While the PRC has established a number of these alternative channels in the Mainland, including e-governance platforms and official blogs, they remain underdeveloped in Hong Kong. Politically, the territory has been caught in awkward limbo between the goal of Western-style free elections and the slowly encroaching communist institutions of the Mainland since its transfer back to China in 1997. The absence of direct communication between Hong Kongers and the Mainland government, through either formal or informal channels, likely contributes to the collective frustration that catalyzed the Umbrella Movement and similar pro-democratic protests. As long as Hong Kong remains in limbo, the PRC's legitimacy will be seriously compromised, and the resulting likelihood of collective action high.

The second theory used in this research project, collective action theory, establishes a lens through which to examine how authoritarian governments identify and react to signs of budding collectivization. Recent findings on censorship conclude that

\footnotetext{
${ }^{139}$ Christian Goebel, "The Information Dilemma: How ICT Strengthen or Weaken Authoritarian Rule.” Statsvetenskaplig tidskrift 115, no. 4(2013): 388.

${ }^{140}$ Ibid.
} 
posts by Chinese netizens criticizing the government are no more likely to be censored than non-political posts. Instead, censorship is used strategically to clip social ties when signs of collective action are evident. ${ }^{141}$ The PRC's ability to predict, prevent, and defuse collective action through calibrated coercion are key to the regime's success and stability. The government's sensitivity makes sense given China's historical tradition of political legitimacy gained through collective action. ${ }^{142}$ Any hint of social unrest is treated as a potential threat to the country's political stability. As a result, China has built the world's most complex, labyrinthine system of information filters, which is made possible by ICTs.

For activists, ICTs came into play as an unsanctioned avenue for political dialogue. Citizens of both Mainland China and Hong Kong are quick to turn to digital mediums as platforms to express their political views. Microblogs and social media sites have been used to voice complaints, express criticism and political opinions, and expose corruption. During the Umbrella Movement, activists turned to informal channels of participation like microblogs, social media platforms, and off-the-grid messaging applications to disseminate information and coordinate demonstrations. The looming threat of networked collective action has spurred the PRC to adapt its governance strategy to a more deliberative approach in order to maintain legitimacy.

Fear of repercussions for publically expressing political opinions are not limited to private citizens. A study conducted in 2008 discovered that 30 percent of Hong Kong

\footnotetext{
${ }^{141}$ King, Pan, and Roberts, "How Censorship in China Allows Government Criticism but Silences Collective Expression," 326-343.

${ }^{142}$ Perry, Challenging the Mandate of Heaven: Social Protest and State Power in China.
} 
journalists admitted to having self-censored their work, and another 58 percent of respondents reported that self-censorship has increased since China absorbed Hong Kong 1997. These numbers reveal a clear concern amongst journalists about publically attaching their names to content that could be considered controversial or politically dangerous. As stated previously, many Umbrella Protestors turned to off-grid mobile phone applications which allowed activists to connect anonymously to one another in order to evade both censorship and surveillance. Anonymity is one of the major advantages that ICTs provide to activists.

Government actions to maintain social order, especially those occurring in a legal or moral gray zone, are often purposefully done in a cloak-and-dagger fashion that makes them difficult to prove. This can create an atmosphere of paranoia, with some instances being justifiable while other instances are purely imagined. While there is enough concrete evidence to suggest that the PRC actively engaged in censorship and some instances of illegal surveillance, the impact of these actions could have possibly been exaggerated by the prevailing atmosphere of suspicion and paranoia among activists. A possible alternative explanation for the results, and a possible avenue of future research on the topic, would be the role that self-censorship and paranoia plays among activists in authoritarian countries.

The PRC's methods for mitigating collective action in Hong Kong are clear, but of equal importance are the PRC's reasons for doing so, especially in light of the fact that Hong Kong's constitution both guarantees freedom of expression and universal suffrage. Circling back to the research question at hand, why did China attempt to undermine Hong Kong activists' legal right to free expression in order to prevent the democratic elections 
promised in Hong Kong's constitution? In summary, the PRC's leadership fears that universal suffrage in Hong Kong will disrupt China's delicate process of authoritarian consolidation. While political leaders in China are typically secretive about the innerworkings of the Communist Party's strategic objectives, evidence suggests that Hong Kong's democratic transition could threaten the party's grip on power in several key ways.

First is the PRC's level of legitimacy. Regimes both democratic and authoritarian are built on a foundation of legitimacy that, if eroded, compromised, or destroyed, typically sound the death knell of the regime in question. A damaged sense of legitimacy can leave regimes vulnerable to internal agitation and demands for regime change. From the perspective of PRC leadership, a most troubling consequence of a democratic Hong Kong can be referred to as "democratic contagion." ${ }^{143}$ PRC leaders undoubtedly watched the Arab Spring unfold as, one by one, long-standing authoritarian regimes succumbed to unrest and political upheaval which spread across the region like sparks to dry grass. Similarly, the same PRC leaders observed how shortly after Hong Kong erupted into protests, social media posts in solidarity with the activists began appearing on Mainlandbased blogs. ${ }^{144}$ Users uploaded posts like "Dictators will always be eliminated, and democracy can’t be stopped," and "Support Hong Kong! If you [the protesters] hang back, our situation today will be your situation tomorrow!!!"145 A few activists in Shanghai even uploaded pictures of themselves with signs bearing pro-democracy

\footnotetext{
${ }^{143}$ Chang, "The Hong Kong Moment: Trouble on China's Periphery," 14-15.

${ }^{144}$ Andrew Jacobs, "Detentions of Hong Kong Protest Sympathizers Reported in Mainland," New York Times. October 1, 2015, http://www.nytimes.com/2014/10/02/world/asia/hong-kong-protest.html

${ }^{145}$ Lu Chen, "China's Internet Censors Seek to Quarantine Hong Kong's 'Democratic Contagion,"” Epoch Times, September 29, 2014.
} 
messages. ${ }^{146}$ While any protest-related posts were quickly deleted, it is clear that ICTs enabled the rapid transmission of ideas and provided an opportunity for solidarity and sympathy between users. What the censors, and by association the PRC leadership, fears is that ICTs can act as a vector for democratic contagion, or the idea that a prodemocracy movement could spread into China via social media and erupt into a full-blow political movement which could prove disastrous to the regime. ${ }^{147}$

Second, a democratic Hong Kong could impact China's foreign relations in ways that are unfavorable to the PRC. Leaders of China's Communist Party have long suspected Western powers of fueling unrest in Hong Kong. In February 2014, just months after the Umbrella Movement, a high-ranking communist party official stated that, "International political forces and anti- $\mathrm{CCP}^{148}$ international organizations are deeply involved, at the political, organizational, societal, and community levels, in transforming Hong Kong into an anti-CCP and anti-China region and making Hong Kong a battlefield of international political power." ${ }^{149}$ Similarly, the former director of China's procommunist publication Xinhua accused foreign and local powers of conspiring to seize power in Hong Kong. ${ }^{150}$ If democratic elections were to come about in Hong Kong, the PRC fears that Western-backed candidates would rise to power and essentially allow foreign powers a back door into China's political sphere.

\footnotetext{
${ }^{146}$ Chang, "The Hong Kong Moment: Trouble on China's Periphery," 14-15.

147 Ibid.

${ }^{148}$ Chinese Communist Party

${ }^{149}$ David Zweig, "Hong Kong's Democracy Movement and Beijing's Fear of Foreign Influence," AsiaPacific Foundation of Canada, September 22, 2015.

${ }^{150}$ Lu Chen, "China's Internet Censors Seek to Quarantine Hong Kong's 'Democratic Contagion."”
} 
In addition to effecting US-China relations, democracy in Hong Kong could potentially shift China's dynamic with Taiwan. ${ }^{151}$ While Hong Kong is China's crown jewel in terms of trade and development, the territory's acquisition was still only one facet of the PRC's long-term plan for consolidation and expansion. Since Taiwan broke away from the Mainland following Mao's ascent in 1949, the PRC has made it a priority to win the island back. The PRC's main point of negotiating Taiwan's return is the success of the "One Country, Two Systems" model of Hong Kong and Macau. ${ }^{152}$ Hong Kong's departure from the model would signal the model's failure, which could potentially nix the PRC's key negotiating tactic with Taiwan. Chinese leaders have repeatedly stressed the importance of winning back Taiwan, so any back-pedaling would be a major blow to the PRC's reunification plan.

For the reasons stated above, the PRC intervened in ways that quarantined the Umbrella Movement, including halting the spread of information online, undermining activists' ability to collectivize, and using surveillance to track and intimidate activists. While the prospect of an angry group of cell phone-wielding students facing down the full force of the PRC seems doomed to failure, evidence from the protests suggests that activists may yet have reason to remain optimistic. Ironically, by refusing to compromise with activists as they have done in the past, the PRC may have actually fanned the flames of the movement so that the conflict grew substantially before finally losing momentum in the winter of 2014. As the PRC cracked down, more activists were galvanized to join the cause, and the international community began to pay attention to the Umbrella

\footnotetext{
${ }^{151}$ Chang, "The Hong Kong Moment: Trouble on China's Periphery," 14-15.

152 "A policy of 'one country, two systems' on Taiwan," Ministry of Foreign Affairs of the People's Republic of China, accessed March 28, 2016.
} 
Movement despite smaller, but ultimately more effective, protests having slipped by in the past. While the initial vigor and energy of the movement died down in 2014, key leaders have vowed to continue their struggle for universal suffrage. The following chapter will provide updates regarding what has happened since the main protests ended in the winter of 2014. Given this information, perhaps the question of why Hong Kong activists failed may be re-framed as why Hong Kong activists have not yet succeeded.

In short, in a world where authoritarian governance unexpectedly survived into the twenty-first century, it is important for researchers to fully explore the tactics these regimes use to perpetuate their rule and the reasoning behind these decisions. ICTs have also radically changed the landscape of civilian participation in social and political dialogues. In the past decade, the world has seen cases of protestors harnessing ICTs to triumph over dictatorships, and other cases where activists wielded the same technology without achieving their collective goals. Case study research can reveal why certain movements succeeded while others did not by taking into account the unique context in which the events took place. The results of these studies can help scholars and policymakers more fully understand the unique obstacles that activists must overcome in order achieve common goals. The project's findings further illuminate the sophisticated mechanisms of ICT-rooted social control that the PRC employs against activists, in addition to providing a more nuanced understanding of the PRC's motivations for intervention, for the benefit of future scholars, policymakers, and activists. 


\section{CHAPTER VII}

\section{CONCLUSION}

This project investigated how the PRC utilized ICTs to diffuse collective action and halt the flow of protest-related information during Hong Kong's 2014 Umbrella Movement. Through a combination of primary sources from social media outlets and interviews, and secondary sources such as news articles and academic research, this thesis has established a contextual analysis of what role ICTs played in maintaining social order during the protests.

In Chapter Three, this project proposed a synthesis of two theories: Authoritarian consolidation theory and collective action theory. Through this theoretical framework, this paper argued that the government would be able to effectively prevent protestors from meeting their goals by diffusing collective action potential and by limiting ICTs as an unsanctioned avenue for political dialogue. Evidence gathered during the protests and the fact that activists did not meet their goal of universal suffrage support the project's hypothesis. That being said, it is important to note the ongoing nature of Hong Kong's unrest. While the future of the territory's bid for universal suffrage appears to be far from over, this paper focused specifically on the three month period between September and December 2014, which marked the height of the protests, and found that during that time the PRC was able to prevent pro-democratic activists from meeting their objective of universal suffrage. 
Over a year has passed since the Umbrella protests exploded at the heart of Hong Kong's government district. This section will provide pertinent updates on the movement, which has lost much of its momentum but is still ultimately ongoing among a small group of devoted activists. A major victory for pro-democracy activists occurred in June 2015 when Hong Kong's legislature vetoed Beijing's controversial electoral reform proposal. The reforms, which generated the initial spark of the Umbrella movement, would have allowed Hong Kong residents to vote for their executive leaders, but candidates would come from a list pre-selected by officials in Beijing. Of the 37 members of the legislative council who voted, 28 rejected the reforms. While this is certainly a huge accomplishment for advocates of universal suffrage, the veto does not guarantee that a more progressive plan will be introduced. The reactions of certain key leaders to the veto are also not altogether promising for the pro-democracy base. Leung Chun-ying, Hong Kong's current leader and a vocal advocate of Beijing, framed the veto as a major loss: "Today 28 legco ${ }^{153}$ members voted against the wishes of the majority of Hong Kong people, and denied them the democratic right to elect the chief executive in the next election." 154 While the tone of Leung's comment was one of disappointment, the PRC's official statement ridiculed the decision, remarking that it, “...fully exposes their selfish interests, hinders Hong Kong's democratic development and damages the essence of Hong Kong's prosperity and stability." ${ }^{155}$ Since making the statement, China has not

\footnotetext{
${ }^{153}$ Legislative Congress

${ }^{154}$ Donny Kwok and Yimou Lee, "Hong Kong vetoes China-backed electoral reform proposal," Reuters, June 18, 2015. http://www.reuters.com/article/2015/06/18/us-hongkong-politicsidUSKBNOOY06320150618

${ }^{155}$ Ibid.
} 
altered its stance or given any indication that it is willing to further negotiate its position on future elections.

Pro-democracy advocates, galvanized by the defeat of the reform package, once again flooded the streets of Hong Kong in July 2015. Activists demanded the resignation of Leung Chun-ying, Hong Kong's pro-Beijing executive leader. With just over 48,000 protestors, the march was one of the smallest of the Umbrella movement, but activists did not necessarily interpret the low turn-out as a sign of concern. Johnson Yeung, an organizer with Hong Kong's Civil Human Rights Watch explained that, “Hong Kong people have been through a lot and they've mobilized massively over the past few years. So after the veto, it's quite natural for them to want to take a rest." ${ }^{156}$ After the victory of early summer, August 2015 dealt a sobering blow to the movement when key protest leaders were charged with the crimes of unlawful assembly and inciting the participation of others. ${ }^{157}$ If the student leaders are convicted, they could spend up to five years in prison. Despite their uncertain futures, the students expressed no regrets for their actions and reiterated their unwavering commitment to bringing the right to vote to Hong Kong. ${ }^{158}$

From a legal standpoint, the Umbrella movement has still not succeeded. Since Beijing first stated its plan to pre-approve all candidates for Hong Kong's future leaders, it has not wavered on its decision, rescinded its position, or offered any opportunity for negotiation with Hong Kong's pro-democratic groups. The reasons for the movement's

\footnotetext{
${ }^{156}$ Yimou Lee and Viola Zhou, "Thousands march for Hong Kong democracy,” Reuters. July 1, 2015. http://www.reuters.com/article/2015/07/01/us-hongkong-china-idUSKCNOPA2VJ20150701 ${ }^{157}$ Alan Wong, "Sit-In leaders are charged in Hong Kong," The New York Times, August 27, 2015. http://www.nytimes.com/2015/08/28/world/asia/sit-in-leaders-are-charged-in-hong-kong.html ${ }^{158}$ Ibid.
} 
failure to achieve its objective are numerous and complex, but on a macro-level, are due to China's goal to further consolidate its authoritarian rule. To allow a territory, especially one as lucrative and financially coveted as Hong Kong, to branch off down a path to democracy would only serve to chip away at China's absolute control. On a micro-level, China's finely tuned program of censorship and surveillance was able to minimize the impact of the movement despite the fact that activists had wide access to ICTs.

Research of post-communist societies in Eastern Europe reveal that access to the internet - even a relatively liberal internet - does not guarantee the success of social or political movements against authoritarian regimes. ${ }^{159}$ Ultimately, the success of a movement is tied to a complexity of factors including the resilience of the regime, the strength of opposition forces, and structural, institutional, or societal barriers. Essentially, ICTs are an asset for activists, but successful movements can only take place if the conditions are right. ${ }^{160}$ In the case of Hong Kong, it is very likely that ICTs aided activists in organization, mobilization, and the communication of their message to a broader audience, but were unable to overcome the structural and institutional barriers unique to Chinese authoritarian rule.

Since the term "Twitter revolution" and "Facebook revolution" were coined in 2009, a number of social movements and political upheavals around the globe have been labeled as products of social media and other forms of communication technologies. While some support this viewpoint of ICTs as liberators of the oppressed, others point

\footnotetext{
${ }^{159}$ Vanderhill, "Limits on the Democratizing Influence of the Internet: Lessons from Post-Soviet States," 31-56.

${ }^{160}$ Ibid.
} 
out that ICTs are susceptible to government manipulation in order to maintain social control and stem collective action.

A future opportunity for research involves investigating the concept of "upgraded authoritarianism" in the context of China and Hong Kong. In essence, upgraded authoritarianism captures the process of how authoritarian regimes adapt and evolve in the face of pressure to democratize, rather than resist or capitulate. ${ }^{161}$ The results of this evolutionary process are "hybrid regimes" which have learned how to balance old mechanisms of authoritarian control with characteristics traditionally associated with democratic regimes, such as economic openness, pseudo-democratic institutions, and the appearance of a relatively unrestricted civil society. ${ }^{162}$ To be certain, these regimes are not actually democracies. Coercive tactics such as intimidation, harassment, and arrests are still employed, and the actions of citizens are carefully policed.

However, upgraded authoritarian regimes are continuously perfecting subtler methods of social control in order to maintain a façade of progress away from the blatantly repressive tactics historically employed by autocratic regimes. While prior research on upgraded authoritarianism focuses on the Middle East, a case study on China would provide insight into how governments in other regions of the world adapt to democratic pressure. Additionally, a deeper understanding of China's tactics would allow activists, scholars, and policy makers ideas on how to potentially counter the process and even gain traction for true democratic change.

\footnotetext{
${ }^{161}$ Steven Heydemann, "Upgrading Authoritarianism in the Arab World," Brooking's Institute Center for Middle East Policy Analysis Papers 13 (2007): 1.

162 Heydemann, "Upgrading Authoritarianism in the Arab World," 3.
} 
This research topic bears prescience as the advancement of technology accelerates and access to ICTs increasingly saturates population centers. Since authoritarian regimes hinge on tight control of information and communication, it goes without saying that ICTs and their ability to fundamentally alter the flow of information will impact the dynamic between the government and the populace. Hong Kong makes for an interesting case since the country's tradition of laissez-faire attitudes towards free trade and expression have essentially primed the populace for democratic discourse. The ongoing political struggle between the people of Hong Kong and the Chinese government appears to be long from over, with student leaders who participated in the Umbrella Movement vowing to make a comeback. Heading into the future, it is likely that technology will play a significant if unpredictable role by potentially lending a voice to the populace's concerns, or by being shaped into another mechanism of authoritarian control. 


\section{REFERENCES}

Ambrosio, Thomas. "Beyond the Transition Paradigm: A Research Agenda for Authoritarian Consolidation." Demokratizatsiya 22 (2014): 471-495.

Anderson, Benedict. Imagined Communities: Reflections on the Origin and Spread of Nationalism. USA: Courier Companies, 1991.

Ansfield, Johnathon. "China Tests New Controls on Twitter-style Services.” The New York Times, July 16, 2010.

Ap, Tiffany. "Can Hong Kong's July 1 pro-democracy march energize political reform bid?” CNN, July 1, 2015. http://www.cnn.com/2015/07/01/asia/hong-kong-julydemocracy-march/

Arquilla, John and David Ronfeldt. The Advent of Netwar (Revisited). Santa Monica: Rand, 2001.

Ayers, José Márcio. "From the Streets to the Internet: the cyber-diffusion of contention." Annals of the American Academy of Political and Social Science 566 (1999): 132-

43.

Baldino, Daniel, and Jarrard Goold. "Iran and the Emergence of Information and Communications Technology: The Evolution of Revolution?" Australian Journal of International Affairs 68 (2014): 17-35.

Basic Law homepage. "Chapter III: Fundamental Rights and Duties of the Residents." Last modified July 13, 2012. http://www.basiclaw.gov.hk/en/basiclawtext/chapter_3.html.

Bayat, Asef. "Islamism and Social Movement Theory." Third World Quarterly 26 (2005): 891-908.

Benoliel, Micha. Global Editor's Network. By Laure Nouraout. October 8, 2014.

Bimber, Bruce. "The Internet and Political Mobilization: Research Note on the 1996 Election Season.” Social Science Computer Review 16.4 (1998): 399-401.

Brunsting, Suzanne and Tom Postmes. "Social Movement Participation in the Digital Age: Predicting offline and online collective action." Small Group Research 33 (2002): 525-554 
Buckley, Chris, Austin Ramzy, and Edward Wong. "Violence Erupts in Hong Kong as Protestors are Assaulted." The New York Times. October 3, 2014. http://www.nytimes.com/2014/10/04/world/asia/hong-kong-protests.html

Castells, Manuel. Rise of the Network Society: The Information Age: Economy, Society, and Culture Volume I. Hoboken: Wiley-Blackwell, 2009.

Chang, Gordon C. “The Hong Kong Moment: Trouble on China's Periphery." World Affairs 177 (2015): 9-15.

Chen, Lu. “China's Internet Censors Seek to Quarantine Hong Kong’s 'Democratic Contagion." Epoch Times, September 29, 2014.

http://www.theepochtimes.com/n3/988821-mainland-chinese-fight-the-internetcensorship-to-support-hong-kong-democracy/

“China Media: White Paper on Hong Kong,” BBC News. June 11, 2014. http://www.bbc.com/news/world-asia-china-27790302

Clinton, Hillary Rodham. "Remarks on Internet Freedom.” Presentation, Washington D.C., January 21, 2010.

Deibert, Ronald, John Palfrey, Rafal Rohozinksi, Johnathan Zittrain. Access Controlled: The Shaping of Power, Rights, and Rule in Cyberspace. Cambridge: The MIT Press, 2010.

Deibert, Ronald, John Palfrey, Rafal Rohozinksi, Johnathan Zittrain. Access Denied: The Practice and Policy of Global Internet Filtering. Cambridge: The MIT Press, 2008.

Diamond, Larry. “Liberation Technology.” Journal of Democracy, 21 (2010): 69-83.

Duggan, Jennifer. "Behind the Great Firewall of China." Maclean's, October 1, 2014.

Edin, Maria. "State Capacity and Local agent Control in China: CPP Cadre Management from a Township Perspective.” China Quarterly 173 (2003): 35-52.

Etling, Bruce, Robert Faris, and John Palfrey. "Political Change in the Digital Age: The Fragility and Promise of Online Organizing," SAIS Review, 30 (2010): 37-49.

Farivar, Cyrus. Internet: Road to Democracy...or Elsewhere? By Tony Cox. NPR, August 15, 2011.

FlorCruz, Jaime A., and Lucrezia Seu. "From snail mail to 4g, China celebrates 20 years 
of Internet connectivity." CNN. April 23, 2014.

http://www.cnn.com/2014/04/23/world/asia/china-internet-20th-anniversary/

Forsythe, Michael, Chris Buckley, and Alan Wong. "In Hong Kong, an Unofficial Election Draws Beijing's Ire.” The New York Times. June 30, 2014. http://www.nytimes.com/2014/06/21/world/asia/in-hong-kong-an-unofficialelection-draws-beijings-ire.html

Foucault, Michel. Discipline and punish: the birth of the prison. New York: Pantheon Books, 1977.

Freedom House. "Freedom in the World 2015." https://freedomhouse.org/report/freedomworld-2015/discarding-democracy-return-iron-fist.

Friedman, Uri. "Will the World Grow More Authoritarian in 2014?" The Atlantic, January 6, 2014. http://www.theatlantic.com/international/archive/2014/01/willthe-world-grow-more-authoritarian-in-2014/282840/

George, Cherian. "Consolidating authoritarian rule: calibrated coercion in Singapore." The Pacific Review 20 (2007): 127-145.

Göbel, Christan. “Authoritarian Consolidation,” European Political Science 10 (2011.): 176-190.

Göbel, Christian. "The Information Dilemma: How ICT Strengthen or Weaken Authoritarian Rule.” Statsvetenskaplig tidskrift 115 (2013): 367-384.

Grammaticas, Damian. "Calls for protests in China met with brutality." BBC News, February 28, 2011. http://www.bbc.com/news/world-asia-pacific-12593328.

Guo, Sujian. "Democratic Transition: A Critical Overview." Issues \& Studies 35 (1999): 133-148.

Habermas, Jürgen. The Theory of Communicative Action: The Critique of Functionalist Reason. Cambridge: Polity Press, 1987.

Harris, Bryan. "Surge in web posts taken down by Hong Kong police sparks censorship fear." South China Morning Post. February 15, 2015. http://www.scmp.com/news/hong-kong/article/1713551/hong-kong-police-pulleddown-more-web-content-last-four-months

Henochowicz, Anne. "Sensitive Words: Hong Kong Protests (Updated)." China Digital 
Times. September 29, 2014. https://chinadigitaltimes.net/2014/09/sensitive-wordshong-kong-protests/

Heydemann, Steven. "Upgrading Authoritarianism in the Arab World." Brooking's Institute Center for Middle East Policy Analysis Papers 13 (2007): 1-38.

Hogg, Chris. "China restores Xinjiang internet.” BBC News, May14, 2010. http://news.bbc.co.uk/2/hi/8682145.stm.

"Hong Kong backs down over Chinese patriotism classes." BBC News, September 8, 2012. http://www.bbc.com/news/world-asia-china-19529867

“Hong Kong Parallel Trade Protests.” BBC News. February 16, 2015. http://www.bbc.com/news/world-asia-china-31483476

"Hong Kong Protestors Mass for Peace Rally." Aljazeera. October 4, 2014. http://www.aljazeera.com/news/asia-pacific/2014/10/hong-kong-protesters-masspeace-rally-201410415640966924.html

“Huge Protest Fills HK Streets," CNN.com, last modified July 2, 2003. http://edition.cnn.com/2003/WORLD/asiapcf/east/07/01/hk.protest/

Hume, Tim. "Alarm in Hong Kong at Chinese White Paper Affirming Beijing Control." CNN, June 13, 2014. http://www.cnn.com/2014/06/11/world/asia/hong-kongbeijing-two-systems-paper/

Iyengar, Rishi. "Hong Kong Government Accused of Using Triads to Attack Student Protestors." Time. October 4, 2014. http://time.com/3464206/blue-ribbonprotestors-occupy-hong-kong-china-democracy-triads/

Jacobs, Andrew. "Detentions of Hong Kong Protest Sympathizers Reported in Mainland." New York Times. October 1, 2015. http://www.nytimes.com/2014/10/02/world/asia/hong-kong-protest.html

Garrett, R. Kelly. "Protest in an Information Society: A Review of Literature on Social Movements and New ICTs." Information, Communication and Society. 9.2 (2006): 202-224.

King, Gary, and Jennifer Pan, and Margaret Roberts. "How Censorship in China Allows Government Criticism but Silences Collective Expression." American Political Science Review 107.2 (2013): 326-343.

Kristoff, Nicholas. “Tear Down This Cyberwall!” The New York Times, June 17, 2009. 
Kwok, Donny, and Yimou Lee. "Hong Kong vetoes China-backed electoral reform proposal." Reuters. June 18, 2015. http://www.reuters.com/article/2015/06/18/ushongkong-politics-idUSKBN0OY06320150618

Lee, Francis. "Power and Strength of Networked Media and Connective Action: The Case of Hong Kong's Umbrella Movement." Communication Research and Practice, 6 (2016): 11-44.

Lee, Francis L. F. and Joseph M. Chan. "Professionalism, Political Orientation, and Perceived Self-Censorship: A Survey Study of Hong Kong Journalists." Paper presented at the annual meeting of the International Communication Association, TBA, Montreal, Quebec, Canada, May 21, 2008.

Lee, Yimou, and Viola Zhou. "Thousands march for Hong Kong democracy." Reuters. July 1, 2015. http://www.reuters.com/article/2015/07/01/us-hongkong-chinaidUSKCNOPA2VJ20150701

Leung, Amy. "Anonymity as Identity: Exploring Collective Identity in Anonymous Cyberactivism." International Journal of Technology, Knowledge and Society 9 (2013): 173-184.

Linz, Juan. J, and Alfred Stepan. Problems of Democratic Transition and Consolidation: Southern Europe, South America, and Post-Communist Europe. Baltimore: Johns Hopkins University Press, 1996.

Luo, Tian. "Grassroots Mobilization of Internet NGO's in China: The Cases of www.1kg.org and ww.geshanghua.org." Paper presented at Fifth International Conference on Information and Communication Technologies and Development, March 12-15 2012, Atlanta, Georgia.

MacKinnon, Rebecca. "China's 'Networked Authoritarianism,"' Journal of Democracy 22.2 (2011): 32-46.

MacLeod, Calum. "Cyberattacks Disrupt Hong Kong Democracy Drive." USA Today, June 19, 2014.

McCaughey, Martha and Michael D. Ayers. Cyberactivism: Online Activism in Theory and Practice. London: Routledge, 2003.

McKenzie, Kevin. "Troubled Waters: Security, Economic Development, And The Senkaku/diaoyu Islands." Thesis, Illinois State University, 2014. http://ir.library.illinoisstate.edu/etd/277. 
Ministry of Foreign Affairs of the People's Republic of China. "A policy of 'one country, two systems' on Taiwan." Accessed March 28, 2016.

http://www.fmprc.gov.cn/mfa_eng/ziliao_665539/3602_665543/3604_665547/t1 8027.shtml.

Morozov, Evgeny. The Net Delusion: The Dark Side of Internet Freedom. New York: Public Affairs, 2012.

Nathan, Andrew J. "China's Changing of the Guard: Authoritarian Resilience.” Journal of Democracy 14.1(2003): 6-17. http://muse.jhu.edu/journals/jod/summary/v014/14.1 nathan.html

Noesselt, Nele. "Microblogs and the Adaptation of the Chinese Party-State's Governance Strategy." Governance: An International Journal of Policy, Administration, and Institutions 27(30): 449-468.

Ng, Ellie. "Hong Kong Activists Fear State Snooping." Foreign Policy. December 3, 2014. http://foreignpolicy.com/2014/12/03/hong-kong-activists-fear-statesnooping/

Office of the Communications Authority. "Key Communications Statistics." Last modified October 23, 2015.

http://www.ofca.gov.hk/en/media_focus/data_statistics/key_stat/

Olson, Mancur. The Logic of Collective Action: Public goods and the theory of groups. Cambridge: Harvard University Press, 1965.

Olson, Parmy. "FireChat Prepares Encryption Feature as it Drives Hong Kong Protests." Forbes, September 29, 2014.

http://www.forbes.com/sites/parmyolson/2014/09/29/firechat-preparesencryption-feature-as-it-drives-hong-kong-protests/

Palmer, Neal A. and Douglas D. Perkins. "Technological Democratization: The Potential Role of ICT in the Social and Political Transformation of China and Beyond." Perspectives on Global Development and Technology 11 (2012): 456-479.

Parker, Emily. "Social Media and Hong Kong Protests." The New York Times. October 1, 2014. http://www.newyorker.com/tech/elements/social-media-hong-kong-protests

Perry, Elizabeth. Challenging the Mandate of Heaven: Social Protest and State Power in China. New York: M.E. Sharpe, 2002.

Phillips, Kerri. “Tracing the History of Hong Kong's Umbrella Movement." Rear Vision. October 28, 2014. 
Sassenberg, Kai and Tom Postmes. "Cognitive and Strategic Processes in Small Groups: Effects of Anonymity of the Self and Anonymity of the Group on Social Influence.” British Journal of Social Psychology 41(2002).

Sataline, Suzanne. "Hong Kong activists fear they are being monitored by Beijing." The Guardian. December 14, 2014. http://www.theguardian.com/world/2014/dec/14/hong-kong-activists-beijingchinese-spying-pro-democracy

Sevastopulo, Demetri. "Teenager Joshua Wong picks up democracy baton in Hong Kong." Financial Times, September 22, 2014. http://www.ft.com/intl/cms/s/0/9d52261c-421e-11e4-981800144feabdc0.html\#axzz3fDoGeZ4z

Shadbolt, Peter. "FireChat in Hong Kong: How an app tapped its way into the protests." CNN. October 16, 2014. http://www.cnn.com/2014/10/16/tech/mobile/tomorrowtransformed-firechat/

Spears, Russell, Martin Lea, and Stephen Lee. "De-Individuation and Group Polarization in Computer-Mediated Communication.” British Journal of Social Psychology 29 (1990): 121-134.

Stout, Kristie Lu. "Hong Kong's 'Umbrella' protest: One year on, what has changed?" CNN. September 28, 2015. http://www.cnn.com/2015/09/27/asia/hong-kongprotests-one-year-later/

The World Factbook. Washington, DC: Central Intelligence Agency. Continually updated. https://www.cia.gov/library/publications/the-world-factbook/.

Van de Donk, Wilfred. Cyberprotest: New Media, Citizens and Social Movements. London: Routledge, 2004.

Vanderhill, Rachel. "Limits on the Democratizing Influence of the Internet: Lessons from Post-Soviet States," Demokratizatsiya 23 (2015): 31-56.

Wong, Alan. "Cyberattack on Hong Kong Vote was Among Largest Ever, Security Chief Says." The New York Times. June 21, 2014.

Wong, Alan. "Sit-In leaders are charged in Hong Kong." The New York Times. August 27, 2015. http://www.nytimes.com/2015/08/28/world/asia/sit-in-leaders-arecharged-in-hong-kong.html 
Wong, Edward. "China's Growth Slows, and Its Political Model Shows Limits." New York Times, May 10, 2012.

http://www.nytimes.com/2012/05/11/world/asia/chinas-unique-economic-modelgets-new-scrutiny.html?_r=1

Woollacott, Emma. "Can China's Social Media Censorship Keep the Lid on Hong Kong Protests?" Forbes. September 29, 2014.

http://www.forbes.com/sites/emmawoollacott/2014/09/29/can-chinas-socialmedia-censorship-keep-the-lid-on-hong-kong-protests/

Xiaojun, Yan. "Regime Inclusion and the Resilience of Authoritarianism: The Local People's Political Consultative Conference in Post-Mao Chinese Politics." The China Journal 66 (2011): 53-75.

Yin, Robert. Case Study Research: Design and Methods. Thousand Oaks: Sage, 2002.

Zeng, Yongnian. Technological Empowerment: The Internet, State, and Society in China, Standford University Press: Redwood City, 2007.

Zhu, Qinfeng and Marko M. Skoric, "The Role of ICT's in Adaptive and Persistent Authoritarianism: A Study of China at the Administrative Division Level." Paper presented at $47^{\text {th }}$ Hawaii International Conference on System Science, Waikoloa, Hawaii, January 6-9, 2014.

Zweig, David. "Hong Kong's Democracy Movement and Beijing's Fear of Foreign Influence." Asia-Pacific Foundation of Canada, September 22, 2015. https://www.asiapacific.ca/canada-asia-agenda/hong-kongs-democracymovement-and-beijings-fear-foreign 